COSTA, N.L., DESCHAMPS, C. e MORAES, A. Estrutura da pastagem, fotossíntese e produtividade de gramíneas forrageiras. PUBVET, Londrina, V. 6, N. 21, Ed. 208, Art. 1387, 2012.

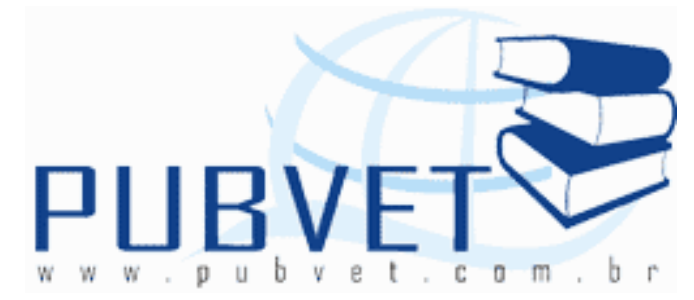

PUBVET, Publicações em Medicina Veterinária e Zootecnia.

\title{
Estrutura da pastagem, fotossíntese e produtividade de gramíneas forrageiras
}

Newton de Lucena Costa ${ }^{1}$, Cícero Deschamps ${ }^{2}$, Anibal de Moraes ${ }^{3}$

${ }^{1}$ Eng. Agr., M.Sc., Embrapa Roraima, Doutorando em Agronomia/Produção Vegetal, UFPR, Curitiba, Paraná.

${ }^{2}$ Eng. Agr., Ph.D., Professor Adjunto, UFPR, Curitiba, Paraná

${ }^{3}$ Eng. Agr., D.Sc., Professor Associado II, UFPR, Curitiba, Paraná

\section{Resumo}

O manejo eficiente e sustentável das pastagens pode ser caracterizado como o controle das relações do sistema pastoril, visando sua maior produção, melhor utilização e persistência, com reflexos positivos no desempenho zootécnico dos animais. A produção de forragem decorre da transformação de energia solar em compostos orgânicos através da fotossíntese, onde o carbono do dióxido de carbono $\left(\mathrm{CO}_{2}\right)$ da atmosfera é combinado com a água e convertido em carboidratos com a utilização da energia solar, processo responsável por mais de $90 \%$ do acúmulo de biomassa nas plantas. Fatores como temperatura, luz, água e nutrientes influenciam o potencial fotossintético da planta forrageira, como decorrência de modificações no seu índice de área foliar e na sua capacidade fotossintética do dossel. A radiação luminosa, considerando-se sua ilimitada disponibilidade, é um dos fatores determinantes ao crescimento das plantas, através dos seus efeitos sobre a fotossíntese e outros processos fisiológicos, como a transpiração e a absorção de água e nutrientes. A seleção de germoplasma forrageiro com arquitetura de plantas e estrutura de dossel 
COSTA, N.L., DESCHAMPS, C. e MORAES, A. Estrutura da pastagem, fotossíntese e produtividade de gramíneas forrageiras. PUBVET, Londrina, V. 6, N. 21, Ed. 208, Art. 1387, 2012.

que maximizem a interceptação e utilização da luz é uma vantagem competitiva, proporcionando maior eficiência na transformação de energia luminosa em química. Neste contexto, práticas de manejo adequadas são essenciais para otimizar a geração e a dinâmica do fluxo de tecidos no ecossistema de pastagem, de modo a equilibrar a conflitante demanda das plantas por área foliar e a sua constante remoção através do consumo animal.

Palavras-chave: área foliar, interceptação de luz, matéria seca, morfogênese

\section{Pasture canopy, photosynthesis and grass forage yield}

\section{Abstract}

Efficient and sustainable pasture management can be characterized as the control of the pastoral system, aiming at its greater production, better utilization and persistence, with positive impacts on animal performance. Forage production stems from the transformation of solar energy into organic compounds from photosynthesis, where the carbon from the carbon dioxide $\left(\mathrm{CO}_{2}\right)$ of the atmosphere is combined with water and converted into carbohydrate, with the utilization of solar energy - a process responsible for more than $90 \%$ of the biomass accumulation in plants. Factors such as light, water and nutrients affect the photosynthetic potential of the forage plant, as a result from alterations in its leaf area and the sward photosynthetic capacity. Regarding its unlimited availability, light radiation is one of the determinant factors to plant growth, through its effect on photosynthesis and other physiological processes, such as transpiration and water and nutrient absorption. The selection of forage germplasm, with plant architecture and sward canopy which maximize light interception and utilization is a competitive advantage, promoting greater efficiency at the transformation of light energy into chemical energy. In this context, adequate management practices are essential to optimize generation and dynamics of tissue flow in the pasture ecosystem, so as to balance the conflicting demand of plants for leaf area and its constant removal through animal intake.

Keywords: dry matter, leaf area, light interception, morphogenesis, 
COSTA, N.L., DESCHAMPS, C. e MORAES, A. Estrutura da pastagem, fotossíntese e produtividade de gramíneas forrageiras. PUBVET, Londrina, V. 6, N. 21, Ed. 208, Art. 1387, 2012.

\section{INTRODUÇÃO}

As pastagens representam a principal e mais barata fonte de alimentos para os ruminantes, mas nem sempre são manejadas de forma adequada, muitas vezes devido à falta de conhecimento sobre suas condições fisiológicas de crescimento e composição nutricional. Manejar uma pastagem de forma adequada significa produzir alimentos em grandes quantidades, além de procurar o máximo valor nutritivo da forragem. A produção de forragem afeta significativamente a capacidade de suporte das pastagens (número de animais que a pastagem comporta sem que sua produtividade ou persistência sejam afetadas), sendo influenciada pela fertilidade do solo, manejo e condições climáticas (COSTA et al., 2007). O valor nutritivo da forragem, representado pela composição química, digestibilidade e aproveitamento da forragem digestível, afeta a produção por animal ( $k g$ de carne/animal, produção de leite/vaca) e depende, primariamente, do consumo de forragem, o qual é afetado pela palatabilidade, velocidade de passagem e disponibilidade da forragem. Associando-se a capacidade de suporte e a produção por animal, tem-se a produção por área de pastagem que é o principal fator que determina a eficiência no manejo de pastagens.

No manejo da pastagem deve-se procurar: a) manter a população e a produtividade das espécies forrageiras, visando à utilização uniforme durante o ano; b) adequar o máximo rendimento e qualidade da forragem produzida, com base no pastejo controlado, visando à produção econômica por animal e por área; c) suprir as exigências nutricionais segundo as diferentes categorias de animal e ciclo de produção e, d) manejar adequadamente o complexo solo/planta/animal para produção econômica, tanto para o produtor como para o consumidor de produtos de origem animal. Dos fatores relacionados ao manejo de pastagem, os mais sujeitos à intervenção direta do homem são: a) a produção e a qualidade da forragem; b) o consumo animal; c) sistema de pastejo adotado; d) equilíbrio da composição botânica da pastagem; e, e) correção e fertilização do solo na formação e manutenção da pastagem (COSTA et al., 2007). 
COSTA, N.L., DESCHAMPS, C. e MORAES, A. Estrutura da pastagem, fotossíntese e produtividade de gramíneas forrageiras. PUBVET, Londrina, V. 6, N. 21, Ed. 208, Art. 1387, 2012.

O manejo eficiente e sustentável das pastagens pode ser caracterizado como o controle das relações do sistema pastoril, visando sua maior produção, melhor utilização e persistência. Em termos práticos, um animal em pastejo representa a forma mais simples do sistema solo-planta-animal. O solo é base do sistema e fonte de nutrientes para a pastagem. A planta é a fonte de nutrientes para o animal e afeta as condições físicas e químicas do solo. 0 animal atua como modificador das condições do solo e da planta. Fatores como temperatura, luz, água e nutrientes influenciam o potencial fotossintético da planta forrageira, como consequência de modificações no índice de área foliar (IAF) e na capacidade fotossintética do dossel.

A produção de forragem decorre da transformação de energia solar em compostos orgânicos através da fotossíntese, onde o carbono do dióxido de carbono $\left(\mathrm{CO}_{2}\right)$ da atmosfera é combinado com a água e convertido em carboidratos com a utilização da energia solar. A conversão de energia, entretanto, é um processo relativamente ineficiente, pois apenas 2 a $5 \%$ da energia luminosa que chega a superfície podem efetivamente serem utilizados no crescimento do dossel (BERNARDES, 1987). A radiação luminosa é o determinante básico do crescimento das plantas através dos seus efeitos sobre a fotossíntese e outros processos fisiológicos, como a transpiração e a absorção de nutrientes. A utilização eficiente da luz pode ser uma vantagem competitiva para as plantas na transformação de energia luminosa em energia química. Dos insumos ambientais primários disponíveis para a produção de biomassa, a radiação solar é o mais passível de otimização, através da seleção de germoplasma forrageiro mais eficiente na sua interceptação e utilização, concomitantemente com a adoção de práticas de manejo que maximizem a absorção de luz e translocação de assimilados (densidade de plantio, consorciação de gramíneas e leguminosas, sistemas de pastejo). Nabinger (1996), considerando a existencia de 12 milhões de ha de pastagens nativas na região Sul do Brasil, estima que se a eficiência de colheita da produtividade primária da pastagem, combinada com a eficiência de conversão de energia luminosa em compostos orgânicos aumentasse apenas 0,01\%, seria possível 
COSTA, N.L., DESCHAMPS, C. e MORAES, A. Estrutura da pastagem, fotossíntese e produtividade de gramíneas forrageiras. PUBVET, Londrina, V. 6, N. 21, Ed. 208, Art. 1387, 2012.

incrementar a oferta de produtos de origem animal em cerca de 19 bilhões de MJ (800.000 t de carne/ano) apenas nesta região e a custo zero.

Neste trabalho são analisados os efeitos da arquitetura de plantas e da estrutura da pastagem e suas interações com a fotossíntese e a produtividade primária da biomassa de gramíneas forrageiras.

\section{Fluxo de energia e produção de forragem}

A produtividade das pastagens pode ser analisada sob três perspectivas: morfologia do perfilho, regulação da área foliar e demografia de perfilhos, variáveis fortemente dependentes da interação genótipo $x$ ambiente (DURAND et al., 1991; MATHEW et al., 2000). O ambiente térmico responsável pela velocidade das reações enzimáticas, o fornecimento de água e nutrientes e, notadamente, o fornecimento de energia e do carbono necessários à estruturação dos órgãos em formação, os quais obedecem a um programa morfogenético. Deste modo, o crescimento de uma pastagem pode ser sintetizado através da integração de dois sub-modelos: um sub-modelo trófico que permite descrever a oferta em carbono através dos fenômenos de interceptação da radiação, da fotossíntese e da respiração e um sub-modelo morfogênico, que descreve a demanda em carbono das partes aéreas (Figura $1)$.

O fluxo de energia dentro do sistema pastoril compreende o captura inicial da energia solar pela vegetação, que a converte em energia química pela fotossíntese nas células clorofiladas das plantas. A ingestão da vegetação pelos herbívoros determina a conversão da energia capturada pelas plantas em produto animal. Na ausência de herbívoros, a energia capturada e transformada pelas plantas é transferida para os decompositores após a senescência. O funcionamento do ecossistema pastagem é caracterizado por fluxos de energia (radiação, calor sensível) e de massa $\left(\mathrm{CO}_{2}, \mathrm{H}_{2} \mathrm{O}, \mathrm{N}\right.$, minerais) entre as plantas de uma comunidade, o solo e atmosfera (LEMAIRE, 2001), representados pelos diferentes processos fisiológicos de captação de energia e nutrientes. Os fluxos são influenciados pelas características estruturais da população de plantas, em termos de tamanho e distribuição espacial das 
COSTA, N.L., DESCHAMPS, C. e MORAES, A. Estrutura da pastagem, fotossíntese e produtividade de gramíneas forrageiras. PUBVET, Londrina, V. 6, N. 21, Ed. 208, Art. 1387, 2012.

superfícies de troca, como área foliar e distribuição radicular. Por outro lado, a interação entre plantas e seu ambiente externo é regulada por fatores fisiológicos, como a difusão estomática de $\mathrm{CO}_{2}$ e água, fotossíntese e respiração, absorção do nitrato ou fixação de nitrogênio (TAIZ; ZEIGER, 2004).

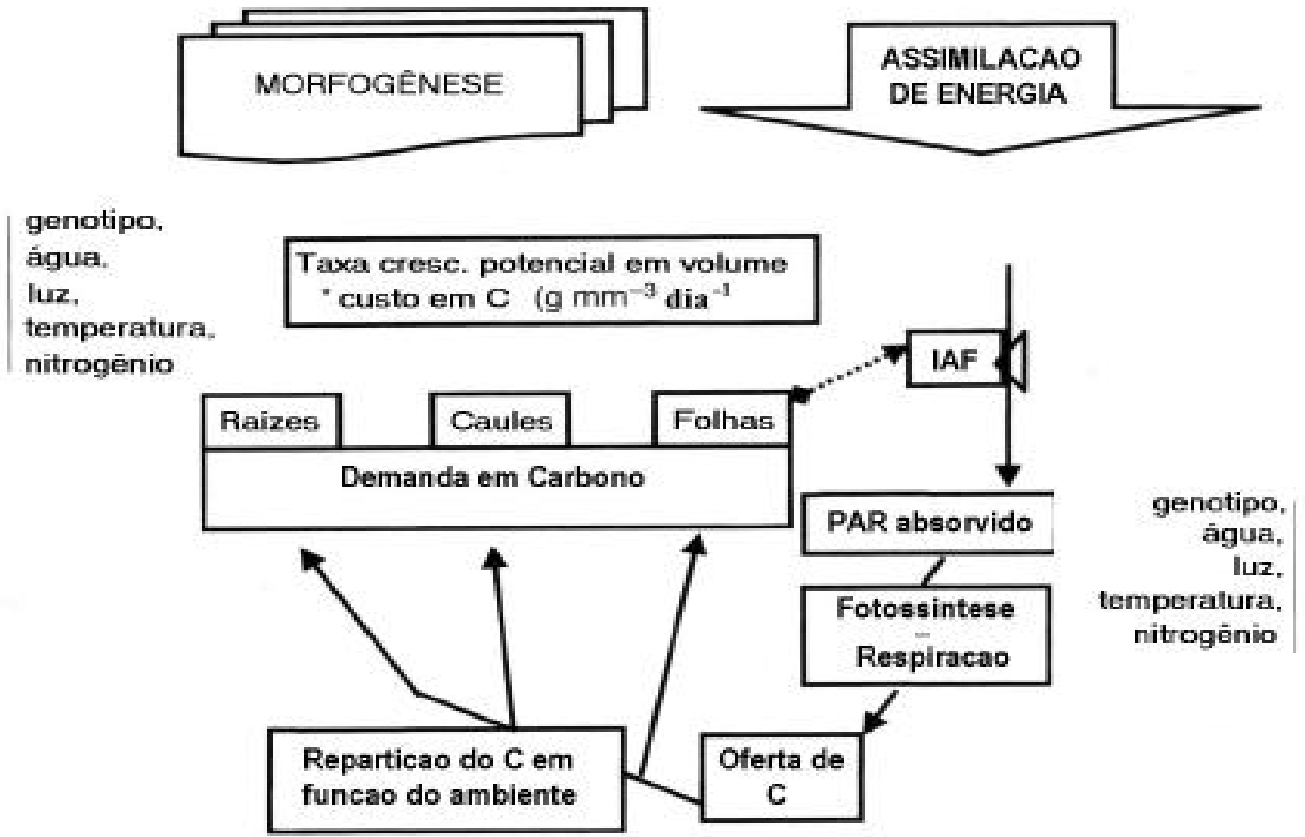

Figura 1. Modelo conceitual de crescimento em função da demanda morfogênica e da oferta ambiental (DURAND et al., 1991)

O papel fundamental da radiação solar decorre de que mais de $90 \%$ do peso seco das plantas provém diretamente da assimilação fotossintética do carbono. A fração mineral absorvida do solo pelas raízes representa apenas 6 a $9 \%$ do peso seco total da planta. Neste contexto, o conhecimento do processo da fotossíntese das comunidades vegetais e os fatores que a afetam, torna-se primordial para a otimização da produtividade primária do ecossistema.

A capacidade produtiva de biomassa de um sistema pastoril pode parecer ilimitada considerando-se o imenso e contínuo suprimento de energia solar. Entretanto, a produtividade primária (biomassa vegetal/área/tempo) é muito baixa na maioria dos ecossistemas naturais ou cultivados. A produtividade primária é limitada basicamente por duas categorias de restrições ecológicas. A primeira restrição diz respeito à qualidade da radiação solar que atinge a 
COSTA, N.L., DESCHAMPS, C. e MORAES, A. Estrutura da pastagem, fotossíntese e produtividade de gramíneas forrageiras. PUBVET, Londrina, V. 6, N. 21, Ed. 208, Art. 1387, 2012.

superfície da terra. Apenas $45 \%$ desta energia estão dentro do espectro da radiação que é efetivo para a fotossíntese (PAR = radiação fotossinteticamente ativa compreendida na faixa de comprimentos de onda entre 400 a $700 \mathrm{~nm}$ ). Os restantes $55 \%$ do espectro não são convertidos em energia química e não formam biomassa. No entanto, esta fração é importante para o ecossistema ao ser absorvida na forma de energia calórica pela atmosfera, solo e vegetação, gerando o ambiente térmico necessário às reações de síntese e para funcionamento do ciclo hidrológico e de nutrientes. A segunda categoria de restrições ecológicas que limitam a produtividade primária envolve a disponibilidade de outros fatores abióticos cujo nível pode impedir a máxima captação da energia solar. Água, temperatura e nutrientes frequentemente limitam o desenvolvimento da área de folhas necessária para a máxima captação da radiação fotossinteticamente ativa incidente (NABINGER, 1997, 2001).

\section{Morfogênese de gramíneas forrageiras}

A morfogênese pode ser definida como a dinâmica de geração e expansão da planta no espaço (CHAPMAN; LEMAIRE, 1993). A emergência, o alongamento, a senescência e a morte de folhas definem o fluxo de biomassa em um relvado e determinam o IAF da pastagem, juntamente com sua população de perfilhos. Por isso, suas respectivas taxas são importantes parâmetros no estabelecimento de modelos alternativos de manejo da pastagem, visando ao aumento de produtividade e eficiência de utilização da forragem produzida (GRANT et al., 1988; PARSONS; PENNING, 1988). Numa pastagem em crescimento vegetativo, na qual aparentemente apenas folhas são produzidas (pois ainda não há alongamento dos entrenós), a morfogênese pode ser descrita por três características básicas: taxa de aparecimento de folhas (TAF) e de alongamento das hastes, taxa de expansão das folhas (TEF) e duração de vida da folha (DVF) (CHAPMAN; LEMAIRE, 1993). Estas características são determinadas geneticamente, porém influenciadas por variáveis ambientais como temperatura, disponibilidade hídrica e de nutrientes (Figura 2). A combinação das variáveis morfogênicas genotípicas determina a 
COSTA, N.L., DESCHAMPS, C. e MORAES, A. Estrutura da pastagem, fotossíntese e produtividade de gramíneas forrageiras. PUBVET, Londrina, V. 6, N. 21, Ed. 208, Art. 1387, 2012.

dinâmica do fluxo de tecidos e as principais características estruturais das pastagens:

- Tamanho da folha, que é determinado pela relação entre TAF e TEF, pois a duração do período de expansão de uma folha é uma fração constante do intervalo de seu aparecimento ou seja do filocrono (ROBSON, 1967; DALE, 1982);

- Densidade de perfilhos, que é parcialmente relacionada com a TAF, que por seu lado determina o número potencial de sítios para o surgimento de perfilhos (DAVIES, 1974). Desta forma, genótipos com alta TAF apresentam alto potencial de perfilhamento e assim determinam uma pastagem com uma densidade de perfilhos mais elevada do que aquelas com baixa TAF;

- Número de folhas vivas por perfilho, que é o produto da TAF pela duração de vida das folhas.

- Relação folha/colmo, que expressa a participação proporcional destes componentes na estrutura morfológica dos perfilhos.

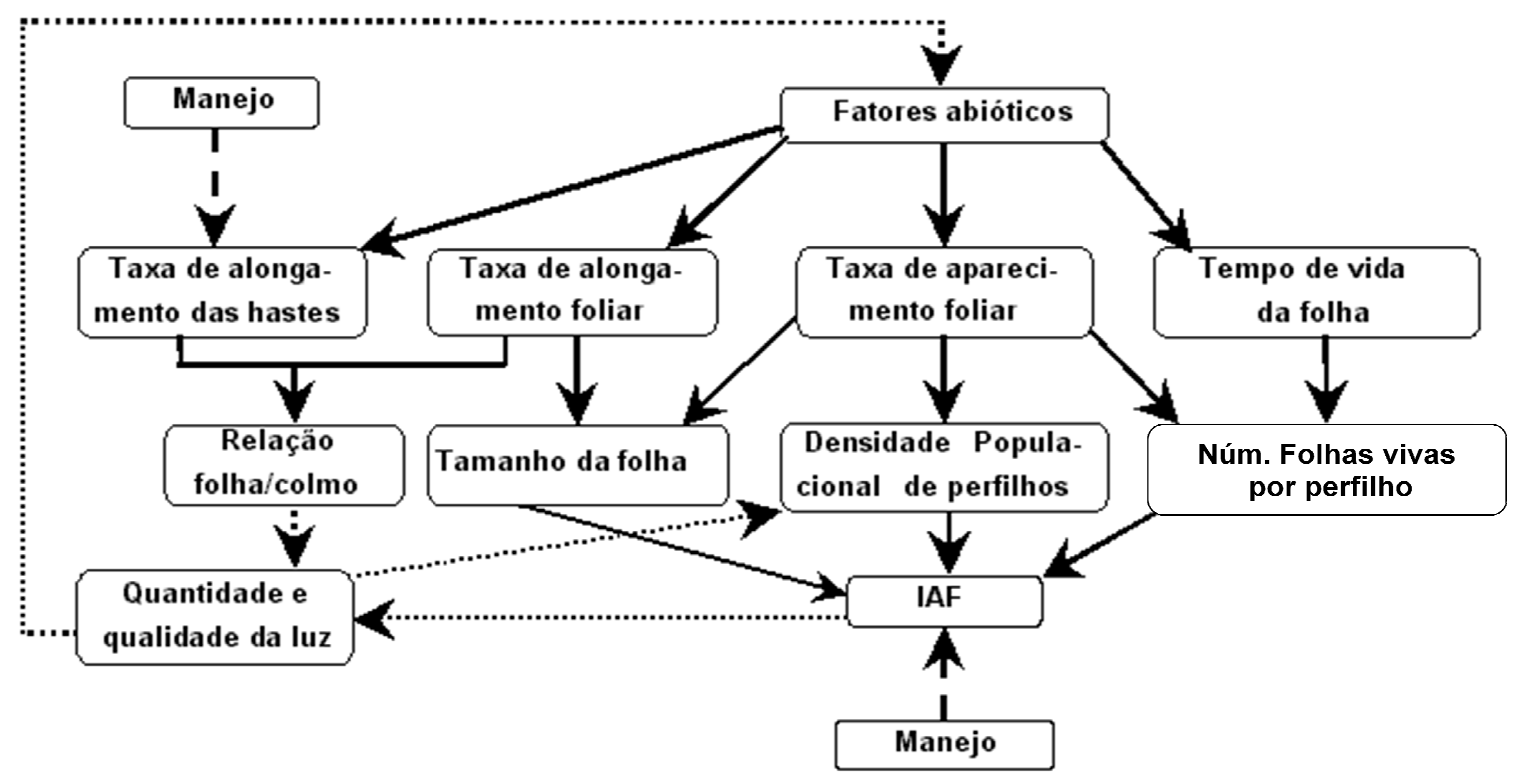

Figura 2. Relação entre características morfogênicas e estruturais da pastagem (LEMAIRE; CHAPMAN, 1996). 
COSTA, N.L., DESCHAMPS, C. e MORAES, A. Estrutura da pastagem, fotossíntese e produtividade de gramíneas forrageiras. PUBVET, Londrina, V. 6, N. 21, Ed. 208, Art. 1387, 2012.

As características morfogênicas são afetadas pela disponibilidade dos recursos tróficos ambientais $\left(\mathrm{CO}_{2}\right.$, nutrientes, água, radiação solar e temperatura) e práticas de manejo (adubação, sistemas de pastejo), as quais alteram as características estruturais da pastagem, condicionando a taxa de lotação, a oferta de forragem e o comportamento ingestivo dos animais (SBRISSIA; DA SILVA, 2001). Em condições normais a flutuação estacional da energia luminosa incidente sobre as plantas resulta em variações na área foliar e na densidade populacional de perfilhos (MATHEW et al., 2000). Ryle \& Powell (1975), em gramíneas temperadas perenes, constataram maior taxa de aparecimento de perfilhos em dias curtos ( $8 \mathrm{~h}$ de luz), comparativamente aos dias longos (16h de luz), contudo o menor número de perfilhos das plantas sob fotoperíodo longo foi compensado pelo maior peso individual. A diminuição da razão vermelho/vermelho distante altera o perfilhamento, retarda 0 desenvolvimento das gemas, diminuindo o tamanho das folhas, sem alterar o filocrono, ocorrendo o inverso quando a relação aumenta (DEGERIBUS et al., 1983; LEMAIRE; CHAPMAN, 1996). Para a maioria das gramíneas temperadas o efeito da temperatura média diária sobre a TAF tende a ser exponencial entre 0 e $12^{\circ} \mathrm{C}$ e linear em valores superiores. As plantas $C_{3}$ apresentam temperatura ótima de crescimento na faixa de 15 a $22^{\circ} \mathrm{C}$ e, as $\mathrm{C}_{4}$ na faixa de 22 a $35^{\circ} \mathrm{C}$. A temperatura influencia o aparecimento, longevidade e senescência de folhas e o desenvolvimento de gemas (GOMIDE, 1997; LEMAIRE, 1997; LEMAIRE; AGNUSDEI, 1999).

\section{Produção de forragem e interceptação de luz}

A produção de forragem depende da atividade fotossintética da folha, capacidade de interceptação da radiação e destino dos produtos assimilados (crescimento, reserva ou respiração). Pearson \& Ison (1987) sugerem como modelo de crescimento potencial em pastagens a equação proposta por Warren-Wilson (1961): $G=\square I\left[1-\mathrm{e}^{(-\mathrm{KL})}\right]$, onde $\mathrm{G}$ é a taxa de crescimento (kg/ha/dia), I é a radiação (MJ/ha), $\square$ é a eficiência fotossintética ( $\mathrm{kg} / \mathrm{MJ}$ ) e a expressão 1- $\mathrm{e}^{(-\mathrm{KL})}$ é uma estimativa da fração da radiação interceptada por uma cultura (dossel) com índice de área foliar $L$ e coeficiente de extinção K. A 
COSTA, N.L., DESCHAMPS, C. e MORAES, A. Estrutura da pastagem, fotossíntese e produtividade de gramíneas forrageiras. PUBVET, Londrina, V. 6, N. 21, Ed. 208, Art. 1387, 2012.

equação sinaliza a importância da eficiência fotoquímica com que a radiação interceptada é utilizada e a influência das características do dossel na intercetapção da radiação, já que o produto $\mathrm{KL}$ apresenta uma relação assintótica com a fração da radiação que é interceptada. Na ausência de fatores ambientais limitantes, os principais fatores que determinam a taxa fotossintética seriam a proporção de radiação incidente que é interceptada, a sua distribuição pela superfície foliar e a eficiência individual da folha na conversão de luz. Nas fases iniciais o crescimento da pastagem é exponencial; a segunda fase é linear e no seu decorrer a sua inclinação é máxima, quando então atinge o teto de produção, permanecendo estável por certo período e logo declinando como conseqüência da interveniência de fatores limitantes, notadamente a baixa penetração de luz no interior do dossel e a elevada proporção de material senescente. A fase linear está associada com o período onde a diferença entre a fotossíntese e a respiração é máxima, gerando balanço positivo máximo de carbono no dossel (Figura 3).

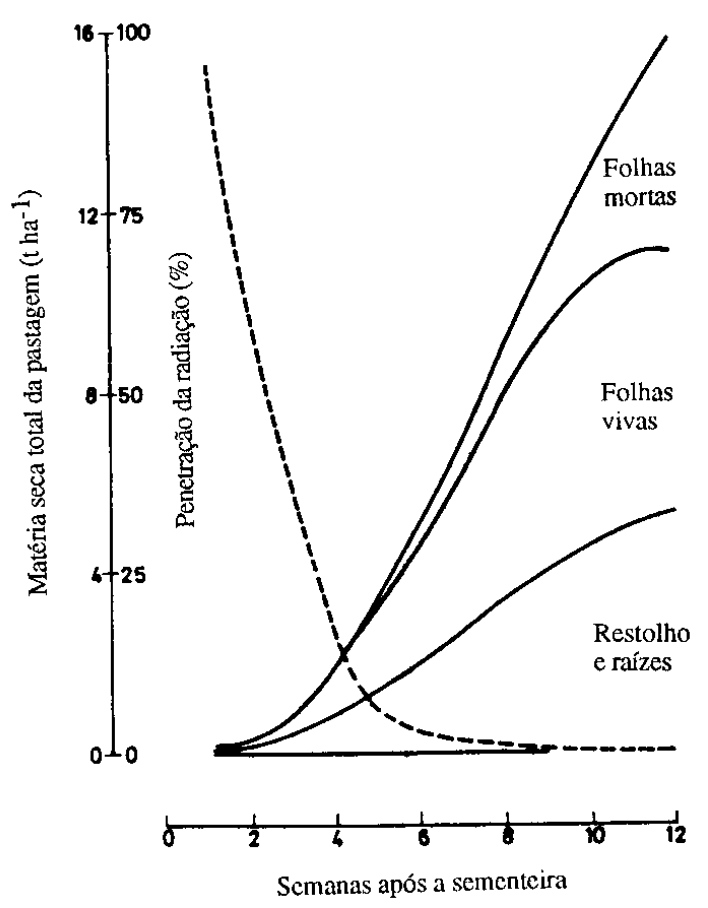

Figura 3. Produção total de MS de uma pastagem de Lolium perenne (L.), repartida por folhas mortas, folhas vivas, restolho e raízes num período de 12 semanas de crescimento. A linha tracejada mostra o percentual da radiação que atinge a base da pastagem (ROBSON et al., 1988) 
COSTA, N.L., DESCHAMPS, C. e MORAES, A. Estrutura da pastagem, fotossíntese e produtividade de gramíneas forrageiras. PUBVET, Londrina, V. 6, N. 21, Ed. 208, Art. 1387, 2012.

A temperatura estabelece forte interação com a radiação luminosa e influencia de forma acentuada e imediata o crescimento da folha, limitando a divisão e o alongamento celular, condicionando a sua eficiência fotossintética, notadamente em elevados níveis de radiação luminosa, o que reflete em diferentes curvas de resposta do crescimento, em função da temperatura do ar das gramíneas e leguminosas forrageiras (Figura 4).

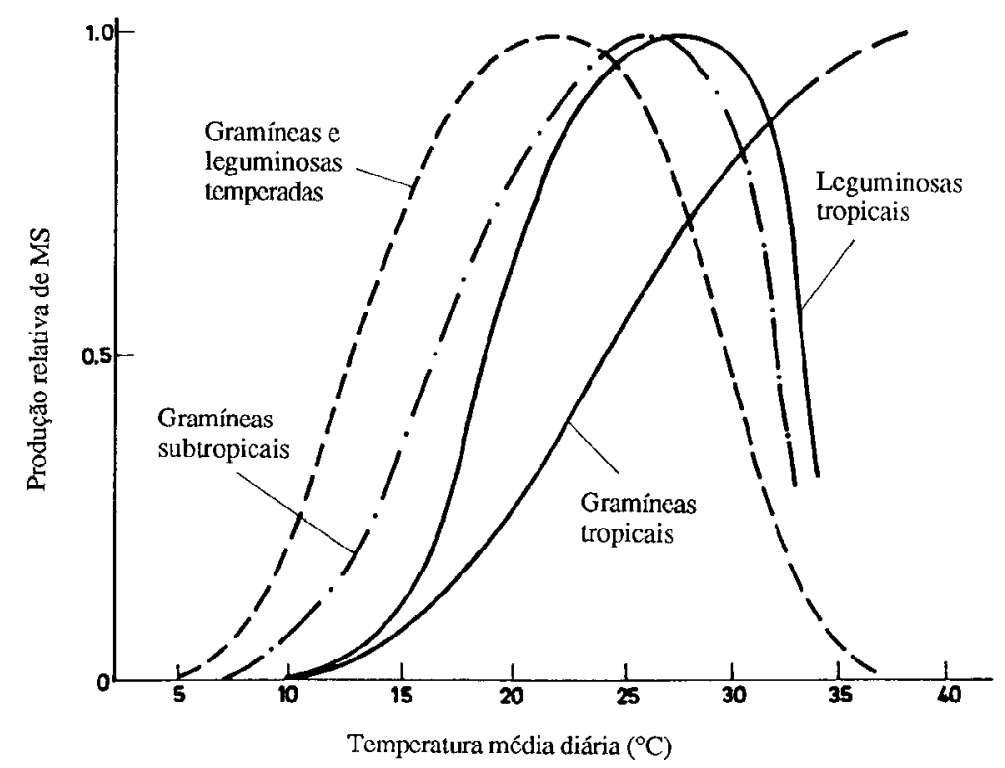

Figura 4. Crescimento potencial de gramíneas e leguminosas forrageiras em resposta à temperatura (PEARSON; ISON, 1987).

A eficiência do uso da radiação pelas plantas depende da interação entre a vegetação e o ambiente, que define como os processos de fotossíntese e transpiração serão afetados pelos elementos climáticos e edáficos ou como a estrutura do dossel afeta a quantidade de radiação incidente que atinge os seus diferentes estratos e sua absorção pelas plantas (RUSSELL et al., 1989). A relação entre a produção de matéria seca (MS) e a quantidade de PAR interceptada ou absorvida tem sido amplamente usada para definir a eficiência de uso da radiação pelas culturas (SIVAKUMAR; VIRMANI, 1984; COSTA et al., 1996). Em condições não limitantes, vários autores demonstraram a linearidade da relação entre a MS total acumulada e a disponibilidade da PAR (BISCOE et al. 1975; MONTEITH，1965, 1977; GALLAGHER; BISCOE, 1978; 
COSTA, N.L., DESCHAMPS, C. e MORAES, A. Estrutura da pastagem, fotossíntese e produtividade de gramíneas forrageiras. PUBVET, Londrina, V. 6, N. 21, Ed. 208, Art. 1387, 2012.

BONHOMME, 2000; SCHÖFFEL; VOLPE, 2001; SILVA JÚNIOR et al., 2009), mormente quando se considera a comunidade de plantas e não a folha isoladamente. Posteriormente o modelo proposto foi utilizado para caracterizar o comportamento individual e em conjunto de várias espécies $\left(C_{3}\right.$ ou $\left.C_{4}\right)$, em termos de potencial para um dado ambiente (GOSSE et al., 1986). Entretanto, nem sempre o aumento linear de MS, em função da radiação interceptada, resulta em aumentos lineares de produtividade (SHIBLES; WEBER, 1965, 1966; SCHÖFFEL; VOLPE, 2001), evidenciando que há outros fatores relacionados com a produtividade, como potencial genético e disponibilidade de água e nutrientes.

A interceptação de luz está condicionada a vários aspectos morfofisiológicos, destacando-se os relativos com a organização espacial das folhas, (densidade de cobertura foliar, posicionamento horizontal ou vertical das folhas e ângulos foliares) e os funcionais, relacionados com a estrutura da planta e o ambiente (idade, tipo, tamanho e propriedades óticas das folhas, saturação lumínica e flutuações na intensidade e qualidade da radiação luminosa)(BERNARDES, 1987). A anatomia da folha é altamente especializada para a absorção de luz (TERASHIMA; HIKOSAKA, 1995). A camada celular mais externa, a epiderme, é tipicamente transparente à luz visível e suas células são frequentemente, convexas, concentrando a luz, de modo que a quantidade que atinge os cloroplastos pode ser muitas vezes maior que a luz disponível no ambiente (VOGELMANN et al., 1996). A difusão do $\mathrm{CO}_{2}$, a intensidade de luz que atinge os cloroplastos, a manutenção da turgescência celular e a translocação de assimilados podem ser afetadas pela extensão do espaço intercelular, a proporção entre parênquima paliçádico e esponjoso, o tamanho e a eficiência dos estômatos, a espessura da cutícula e a eficiência do sistema vascular (TAIZ; ZEIGER, 2004).

A distribuição estacional da radiação luminosa é o fator climático mais limitante à produção de plantas forrageiras, cuja eficiência de utilização é negativamente afetada por outros fatores, tais como: baixas temperaturas, latitude, deficiência de água e limitação de nutrientes no solo, particularmente 
COSTA, N.L., DESCHAMPS, C. e MORAES, A. Estrutura da pastagem, fotossíntese e produtividade de gramíneas forrageiras. PUBVET, Londrina, V. 6, N. 21, Ed. 208, Art. 1387, 2012.

do nitrogênio (PEDREIRA, 1995). Um modelo para estimar a produção de biomassa, em função da latitude e do tipo de rota fotossintética da planta $\left(\mathrm{C}_{3}\right.$ ou $C_{4}$ ) foi proposto por Snaydon (1991), sendo descrito pela equação: $B=36$ $-0,35 \pm 0,08 L-10 \pm 3 A+0,3 \pm 3$ C, onde, $B=$ produção de biomassa (t/ha); $L=$ latitude em graus; $A=$ ciclo da cultura (anuais $=1$ e perenes $=0$ ) e $C=$ rota fotossintética $\left(C_{3}=0\right.$ e $\left.C_{4}=1\right)$. $O$ modelo preconiza uma redução de 0,35 t/ha para cada incremento de um grau na latitude, possivelmente como conseqüência de temperaturas mais baixas e menor duração da estação de crescimento em altas latitudes; as culturas perenes produzem, em média, $10 \mathrm{t}$ /ha de biomassa a mais que as anuais e as plantas $\mathrm{C}_{4}$ superam a produtividade das $\mathrm{C}_{3}$ em apenas 0,31 t/ha. As plantas forrageiras do tipo $\mathrm{C}_{4}$, bem adaptadas ao clima tropical, superam as do tipo $\mathrm{C}_{3}$ quanto à capacidade fotossintética, taxa de acúmulo de forragem e eficiência no uso de água e nutrientes. Ademais, as plantas $C_{3}$ saturam-se de luz em intensidades luminosas mais baixas que as $C_{4}$ (AGATA et al., 1985; LUDLOW, 1985). Contudo, variações significativas podem ser observadas na produtividade de biomassa quando se comparam espécies $C_{4}$, entre si ou com outras do tipo $C_{3}$. Em condições ambientais semelhantes, as produtividades médias anuais da cana-de-açúcar (Saccharum officinarum) e do capim-elefante (Pennisetum purpureum) foram o dobro da verificada com capim-bermuda (Cynodon dactylon), todas espécies com rota fotossintética $\mathrm{C}_{4}$ (LOOMIS; GERAKIS, 1975). Hofstra \& Stienstra (1977), avaliando a produtividade de biomassa de uma gramínea $\mathrm{C}_{3}$ tolerante à sombra (Oplismenus compositus) e duas gramíneas $\mathrm{C}_{4}$ (Axonopus compressus e Setaria plicata) normalmente encontradas em ambientes abertos, sob diferentes níveis de irradiância, constataram que, durante o período chuvoso, a taxa relativa de crescimento da gramínea $\mathrm{C}_{3}$ foi inferior a de $S$. plicata, porém superior a de $A$. compressus, enquanto que durante $\mathrm{o}$ período seco as três gramíneas apresentaram desempenhos produtivos semelhantes.

A arquitetura do dossel interfere na distribuição da luz dentro da população de plantas e na circulação de ar afetando os processos de transferência de $\mathrm{CO}_{2}$ e evapotranspiração, sendo o fator determinante dos 
COSTA, N.L., DESCHAMPS, C. e MORAES, A. Estrutura da pastagem, fotossíntese e produtividade de gramíneas forrageiras. PUBVET, Londrina, V. 6, N. 21, Ed. 208, Art. 1387, 2012.

padrões de interceptação luminosa pelas plantas e, para tanto, a sua altura é a característica mais importante para a maximização de sua habilidade competitiva pela luz (LOOMIS; WILLIAMS, 1969). Para a máxima produtividade de forragem é primordial que toda a luz incidente seja utilizada pelo tecido fotossintético, contudo alterações na interceptação luminosa podem ser influenciadas pelo estádio de crescimento, espécie da planta e estação do ano (BROUGHAM, 1957). As plantas promovem ajustes fisiológicos que reduzem os riscos de danos em alta luminosidade, destacando-se: a) movimentação dos cloroplastos de um lado ao outro da célula (ciclose); b) orientação das folhas ao ponto delas ficarem alinhadas paralelamente à incidência dos raios solares e, assim, absorverem menos luz; c) características estruturais e químicas da folha que reduzem a quantidade de luz que alcança o cloroplasto (superfície brilhante ou reflectiva; cutícula mais espesa e células da epiderme com maiores teores de antocianina que absorve comprimentos de ondas curtos e mais danosos).

\section{1. Índice de Área Foliar}

É a relação entre a área de folhas e a superfície de solo que elas cobrem, expressando o potencial de rendimento de forragem, relacionado com a utilização da energia solar, através da fotossíntese. Ele representa a disponibilidade de superfície assimiladora de $\mathrm{CO}_{2}$ e da radiação fotossinteticamente ativa e de perdas de água (transpiração) da população de plantas. Com o aumento da interceptação da luz solar ocorrem, simultaneamente, incrementos no rendimento de forragem, até ser atingido um platô, quando as folhas mais velhas entram em senescência e são sombreadas pelas mais novas, acarretando a diminuição da eficiência fotossintética com menores taxas de crescimento. Quando a planta absorve praticamente toda a radiação incidente, sem que haja auto-sombreamento, ela se encontra no denominado IAFótimo. Quando o IAF proporciona $95 \%$ de interceptação luminosa, é denominado de IAFcrítico, enquanto que o IAFteto é aquele que ocorre quando a taxa de formação de novas folhas é igual à de 
COSTA, N.L., DESCHAMPS, C. e MORAES, A. Estrutura da pastagem, fotossíntese e produtividade de gramíneas forrageiras. PUBVET, Londrina, V. 6, N. 21, Ed. 208, Art. 1387, 2012.

senescência das folhas inferiores, ou seja, é o máximo IAF que a planta alcança. Em Rondônia, Costa (2004) verificou que os IAF de genótipos de $B$. brizantha e $B$. humidicola foram diretamente proporcionais à idade das plantas e positiva e significativamente correlacionados com a produtividade de MS, sendo os maiores valores registrados aos 35 e 42 dias de rebrota (Tabela 1). Para Paspalum atratum cv. Pojuca, o IAF foi significativamente incrementado em plantas com até 49 dias de rebrota, contudo as taxas de assimilação aparente - parâmetro que representa a diferença entre a fotossíntese e a respiração, ou seja, é uma estimativa da fotossíntese líquida, devido ao autosombreamento das folhas - foram máximas no período compreendido entre 14 e 28 dias de rebrota (COSTA et al, 2007).

Tabela 1. Índice de área foliar de genótipos de B. brizantha, B. dictyoneura e B. humidicola, em função da idade das plantas.

\begin{tabular}{lccccc}
\hline Gramíneas & \multicolumn{5}{c}{ Idades das Plantas (dias) } \\
\cline { 2 - 6 } & 14 & 21 & 28 & 35 & 42 \\
\hline B. brizantha cv. Marandu & 0,53 & 0,89 & 1,57 & 2,01 & 2,33 \\
B. brizantha cv. Xaraés & 0,61 & 1,41 & 2,30 & 2,86 & 3,07 \\
B. brizantha BRA-003395 & 0,52 & 0,79 & 1,32 & 1,70 & 1,98 \\
B. dictyoneura & 0,80 & 1,57 & 2,44 & 2,97 & 3,38 \\
B. humidicola & 0,73 & 0,92 & 1,45 & 2,26 & 2,58 \\
B. humidicola BRA-003564 & 0,86 & 1,17 & 1,80 & 2,64 & 2,94 \\
B. humidicola BRA-003545 & 0,98 & 1,40 & 1,93 & 2,71 & 2,89 \\
\hline
\end{tabular}

Fonte: COSTA (2004)

O IAFótimo de uma planta forrageira é aquele associado com altos rendimentos, bem distribuídos ao longo da estação de crescimento. Normalmente, ocorre quando as folhas interceptam cerca de $90 \%$ da radiação incidente, proporcionando as maiores taxas de crescimento da cultura (TCC = $\mathrm{kg}$ de $\mathrm{MS} / \mathrm{ha} / \mathrm{dia}$ ). Abaixo do IAFótimo, as TCC seriam menores quanto mais incompleta a interceptação da luz (menor IAF) e acima do IAF $_{\text {ótimo, a redução }}$ da TCC seria decorrente do aumento das perdas respiratórias, consequência do sobreamento excessivo, que resulta num balanço negativo de carbono (HAY; 
COSTA, N.L., DESCHAMPS, C. e MORAES, A. Estrutura da pastagem, fotossíntese e produtividade de gramíneas forrageiras. PUBVET, Londrina, V. 6, N. 21, Ed. 208, Art. 1387, 2012.

WALKER, 1989). Em gramíneas temperadas, Sheehy \& Cooper (1973) constataram que maiores TCC foram correlacionadas com a morfologia da planta e com o coeficiente de extinção luminosa $\mathrm{K}\left(\mathrm{K}=-\left[\log _{\mathrm{e}}\left(\mathrm{I} / \mathrm{I}_{0}\right)\right] / \mathrm{IAF}\right.$, onde I e $I_{0}$ são os valores de irradiância abaixo e acima da folhagem, respectivamente). As taxas fotossintéticas de folhas individuais foram semelhantes, contudo a eficiência de conversão da energia luminosa foi maior nas plantas eretas $(7,8 \%)$ que nas prostradas $(3,9 \%)$. O valor ótimo de IAF varia com estação do ano, sendo proporcional à intensidade luminosa e quando a proporção de radiação direta sobre a incidente aumenta, além de ser dependente da arquitetura e composição botânica morfológica do dossel. As leguminosas, por apresentarem as folhas na posição horizontal, são capazes de interceptarem mais luz por unidade de área foliar do que as gramíneas, com suas folhas semi-eretas. Em Rondônia, Costa (2004), avaliando a morfogênese de três genótipos de $B$. humidicola, verificou que o IAFótimo ocorreu com plantas aos 35 dias de rebrota, enquanto que para Brachiaria dictyoneura e $P$. maximum cv. Centenário, este ocorreu no período entre 35 e 42 dias após o corte das plantas (COSTA et al., 2007).

O IAF remanescente, ou seja, a quantidade de tecido fotossinteticamente ativo que permanece na planta após o pastejo ou corte, é de fundamental importância no manejo de uma pastagem. A rebrota utilizará assimilados da fotossíntese das folhas remanescentes, desde que a quantidade de $\mathrm{CO}_{2}$ produzida seja superior ou igual à quantidade de $\mathrm{CO}_{2}$ liberada pela planta durante a respiração. No entanto, deve-se considerar que a eficiência fotossintética diminui à medida que as folhas envelhecem. Se as plantas forrageiras forem manejadas sob desfolha intensa, o crescimento do sistema radicular e o acúmulo de carboidratos de reservas serão prejudicados.

O nível de eficiência fotossintética de folhas novas depende do ambiente em que se desenvolvem. Se a pastagem é constituída por plantas de hábito de crescimento prostrado, o desenvolvimento de folhas novas ocorrerá em um ambiente de baixa intensidade luminosa e terá menor capacidade fotossintética (ROBSON et al., 1988), o mesmo acontecendo para as folhas de 
COSTA, N.L., DESCHAMPS, C. e MORAES, A. Estrutura da pastagem, fotossíntese e produtividade de gramíneas forrageiras. PUBVET, Londrina, V. 6, N. 21, Ed. 208, Art. 1387, 2012.

perfilhos que iniciam o crescimento da base de touceiras de espécies com hábito de crescimento cespitoso. Quando o sombreamento altera o suprimento de carbono da planta ocorre competição entre folhas e gemas axilares diminuindo a taxa de perfilhamento, como resultado da resposta fotomorfogenética das plantas forrageiras, originando um processo de mortedependente de densidade populacional caracterizado por uma relação inversa entre tamanho e número de perfilhos (LEMAIRE, 2001). Para $P$. atratum cv. Pojuca, Costa (2004) observou que o vigor de rebrota foi diretamente proporcional ao IAF remanescente, sendo os maiores rendimentos de MS obtidos com cortes a $30 \mathrm{~cm}(29,1 \mathrm{t} / \mathrm{ha})$, comparativamente a $15 \mathrm{~cm}$ acima do solo (23,4 t/ha). Da mesma forma, Costa et al. (2007), em pastagens de $P$. atratum cv. Pojuca, submetidas a pastejo rotativo (7 dias de ocupação por 21 dias de descanso), verificaram que a carga animal afetou significativamente o IAF remanescente e, consequentemente, a disponibilidade de forragem e MS residual de folhas (Tabela 2 ).

Tabela 2. Disponibilidade de matéria seca (DMS), matéria seca residual de folhas (MSRF), matéria seca da resteva (MSR), índice de área foliar (IAF) e índice de área foliar remanescente (IAFR) de Paspalum atratum cv. Pojuca, em função da carga animal.

\begin{tabular}{lcccccc}
\hline Estação & $\begin{array}{c}\text { Carga Animal } \\
(\mathrm{UA} / \mathrm{ha})\end{array}$ & $\begin{array}{c}\text { DMS } \\
(\mathrm{t} / \mathrm{ha})\end{array}$ & $\begin{array}{c}\text { MSRF } \\
(\mathrm{t} / \mathrm{ha})\end{array}$ & $\begin{array}{c}\text { MSR } \\
(\mathrm{t} / \mathrm{ha})\end{array}$ & IAF & IAFR \\
\hline Chuvosa1 & 2,0 & $3,58 \mathrm{a}$ & $1,30 \mathrm{a}$ & $2,84 \mathrm{a}$ & $2,78 \mathrm{a}$ & $0,69 \mathrm{a}$ \\
& 3,0 & $2,74 \mathrm{~b}$ & $0,91 \mathrm{~b}$ & $2,65 \mathrm{a}$ & $1,95 \mathrm{~b}$ & $0,52 \mathrm{~b}$ \\
Seca2 & 2,0 & $2,03 \mathrm{c}$ & $0,41 \mathrm{c}$ & $1,74 \mathrm{~b}$ & $1,76 \mathrm{~b}$ & $0,32 \mathrm{c}$ \\
& 3,0 & $1,41 \mathrm{~d}$ & $0,28 \mathrm{~d}$ & $1,65 \mathrm{~b}$ & $0,80 \mathrm{c}$ & $0,27 \mathrm{c}$ \\
\hline
\end{tabular}

- Médias seguidas de mesma letra não diferem entre si $(P>0,05)$ pelo teste de Duncan.

${ }^{1}$ Outubro a maio $=1.897 \mathrm{~mm} ;{ }^{2}$ Junho a setembro $=278 \mathrm{~mm}$. Fonte: COSTA et al. $(2007)$.

\subsection{Eficiência Fotossintética das Folhas}

A taxa de fotossíntese da folha é influenciada pelas condições ambientais, idade da folha e ambiente em que a folha formou o seu aparelho fotossintético. A arquitetura do dossel forrageiro define o grau de exposição das folhas à luz, onde são encontradas folhas das mais variadas idades que contribuem de forma distinta para a fotossíntese total. A idade da folha traduz-se numa 
COSTA, N.L., DESCHAMPS, C. e MORAES, A. Estrutura da pastagem, fotossíntese e produtividade de gramíneas forrageiras. PUBVET, Londrina, V. 6, N. 21, Ed. 208, Art. 1387, 2012.

acentuada e progressiva redução da sua eficiência fotossintética após sua completa expansão e antes de evidenciar sinais de senescência (NABINGER, 1996). A redução é atenuada se ocorrer em período de baixa intensidade de radiação ou baixas temperaturas. Finalmente, $\mathrm{o}$ ambiente em que se desenvolve o aparelho fotossintético da folha condiciona a sua eficiência futura, revelando a folha neste aspecto pouca capacidade de adaptação (COSTA et al., 2011). A influência mais marcante é a da intensidade da radiação, já que as folhas que se formam em condições de baixa radiação (folhas de sombra), evidenciam baixas taxas fotossintéticas quando expostas a elevada radiação, embora sejam mais eficientes a baixos valores de radiação e apresentem menores valores de respiração noturna (Figura 5). Estes aspectos têm grande importância para o maneio das pastagens, já que as baixas intensidades de radiação a que as folhas se formam podem resultar da elevada densidade da vegetação e do maior intervalo de tempo para a sua utilização (ROBSON et al., 1988).
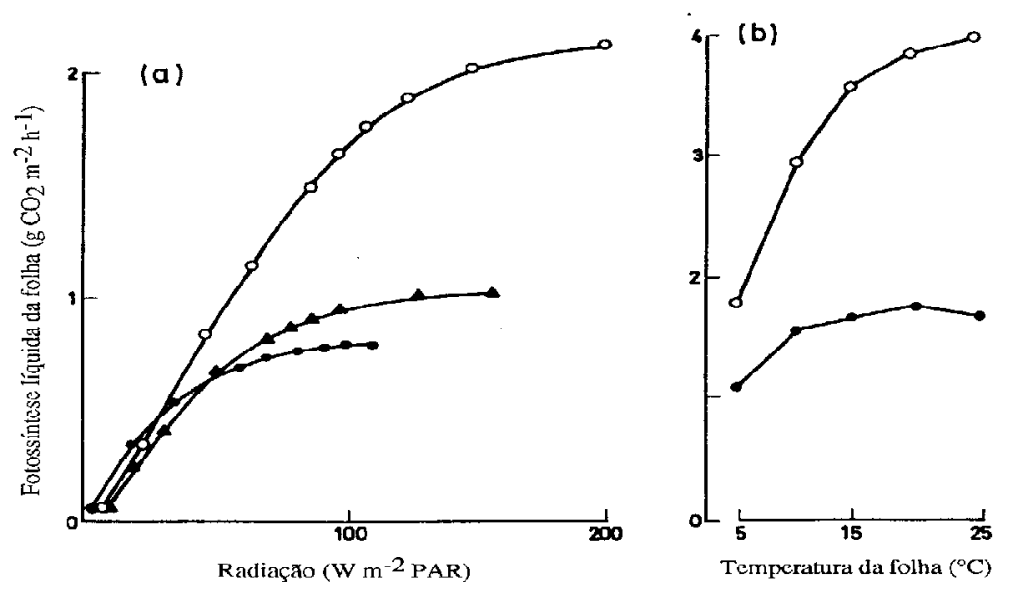

Figura 5. Taxas de fotossíntese líquida de folhas de Lolium perenne (L.) sob concentração normal de $\mathrm{CO}_{2}$ no ambiente (a) Efeito da intensidade da radiação em que as folhas se formaram (o) $110 \mathrm{~W} / \mathrm{m}^{2} ;(\boldsymbol{\Delta}) 45 \mathrm{~W} / \mathrm{m}^{2} ;(\bullet) 16 \mathrm{~W} / \mathrm{m}^{2}$ : (b) Efeito da temperatura a diferentes níveis de radiação (o) $250 \mathrm{~W} / \mathrm{m}^{2}$ ou (•) $50 \mathrm{~W} / \mathrm{m}^{2}$ (ROBSON et al., 1988). 
COSTA, N.L., DESCHAMPS, C. e MORAES, A. Estrutura da pastagem, fotossíntese e produtividade de gramíneas forrageiras. PUBVET, Londrina, V. 6, N. 21, Ed. 208, Art. 1387, 2012.

As folhas jovens têm taxa fotossintética por unidade de área maior que as mais velhas sob condições de quantidade de radiação incidente elevada, e a sua disposição no perfil vertical do dossel pode otimizar a eficiência de utilização da luz (LAWLOR, 1995). Recomenda-se a manutenção do dossel com um IAF alto o suficiente para assegurar uma interceptação luminosa efetiva e ao mesmo tempo proporcionar uma alta eficiência fotossintética de folhas individuais, assegurando que folhas jovens sejam expostas, o quanto antes, à luz direta e que não sejam sombreadas pelas mais velhas e senescentes (HODGSON, 1990). Individualmente as folhas apresentam grande variação em sua capacidade fotossintética, condicionada por vários fatores, como quantidade de radiação solar incidente, temperatura, suprimento de água e, principalmente, o estádio de desenvolvimento da folha (ZELITCH, 1982; BRAGA et al., 2006). Ao longo do dossel as variações de temperatura e luminosidade e a diferença na idade fisiológica das folhas são grandes, o que Ihes confere diferentes potenciais fotossintéticos (LOOMIS \& WILLIAMS, 1969). À medida que a radiação luminosa que penetra no dossel vai diminuindo de intensidade, ocorre o ponto de compensação da luz, ou seja, quando a quantidade de luz que atinge uma folha fotossintetizante, em que a absorção fotossintética do $\mathrm{CO}_{2}$ está em exato equilíbrio com a liberação de $\mathrm{CO}_{2}$ pela respiração. Treharne et al. (1968) reportaram uma redução de $75 \%$ no teor de clorofila de folhas de Dactylis glomerata, aos 35 dias de rebrota, comparativamente a observada aos 5 dias após a desfolha da pastagem. Estes resultados foram corroborados por Parsons et al. (1983) que constataram que as folhas expandidas ou em expansão, apesar de representarem apenas $42 \%$ da área foliar, responderam por $77 \%$ da fotossíntese líquida do dossel.

As folhas recém-expandidas apresentam taxas fotossintéticas máximas e seus assimilados são utilizados em sua manutenção e para atender às necessidades do meristema apical, sistema radicular e das folhas em formação. Folhas com limbo parcialmente exposto não translocam assimilados para outras partes dos perfilhos, utilizando-os em seu próprio desenvolvimento (MILTHORPE; DAVIDSON, 1966). A idade das folhas remanescentes após a 
COSTA, N.L., DESCHAMPS, C. e MORAES, A. Estrutura da pastagem, fotossíntese e produtividade de gramíneas forrageiras. PUBVET, Londrina, V. 6, N. 21, Ed. 208, Art. 1387, 2012.

desfolha e sua relação com a eficiência de absorção de $\mathrm{CO}_{2}$ na taxa de acúmulo de forragem desempenha fundamental importância (BROWN et al., 1966). Em pastagens de Panicum maximum cv. Tobiatã, as taxas fotossintéticas foram variáveis em função do ponto de medição na lâmina foliar, sendo os maiores valores registrados na parte mediana e no ápice foliar (SALOMÃO et al., 2005). Acock et al. (1978) correlacionaram a baixa atividade fotossintética de folhas basais com a diminuição de sua condutância estomática e respiração. Em Brachiaria brizantha cv. Xaraés, Braga et al. (2002) constataram reduções do ponto de compensação luminosa (36 para $10 \mu \mathrm{mol}$ de fótons $\left.\mathrm{m}^{-2} \mathrm{~s}^{-1}\right)$ e na taxa respiratória $\left(3,0\right.$ para $\left.1,0 \mathrm{CO}_{2} \mathrm{~m}^{-2} \mathrm{~s}^{-1}\right)$, comparando folhas jovens em expansão e mais velhas, respectivamente. Mello et al. (2001) avaliaram a resposta fotossintética de $P$. maximum cv. Tanzânia-1, sob quatro níveis de temperatura foliar $\left(25,30,35\right.$ e $\left.40^{\circ} \mathrm{C}\right)$ e, observaram uma taxa máxima de fotossíntese líquida $\left(34,57 \square \mathrm{mol}\right.$ de $\left.\mathrm{CO} 2 \mathrm{~m}^{-2} \mathrm{~s}^{-1}\right)$ na temperatura de $35^{\circ} \mathrm{C}$, enquanto que sob $40^{\circ} \mathrm{C}$, as respostas foram mais variáveis e ocorrendo redução na taxa máxima de fotossíntese líquida $\left(27,53 \square \mathrm{mol}\right.$ de $\left.\mathrm{CO} 2 \mathrm{~m}^{-2} \mathrm{~s}^{-1}\right)$, devido ao estresse térmico causado por esse nível de temperatura nas folhas da gramínea.

\subsection{Arquitetura das plantas e estrutura da pastagem}

A arquitetura da plantas influencia a interceptação da radiação e exerce fundamental importância na transmissão da luz no interior do dossel, condicionando o nível de radiação em que as folhas inseridas na porção basal ou mediana da planta formarão seu aparelho fotossintético e, consequentemente, seu nível de eficiência na absorção e produção de compostos orgânicos. A interceptação de radiação solar é uma função do índice de área foliar e do coeficiente de extinção luminosa (K). O coeficiente de extinção luminosa mostra a fração de radiação extinta ao longo do dossel vegetativo, devido à menor transmissividade luminosa (MONSI; SAEXI, 1953). A densidade da área foliar de um dossel forrageiro é determinada primeiramente pela separação vertical das folhas que, por sua vez, é determinada pelo comprimento dos internódios das hastes. Quando a distância 
COSTA, N.L., DESCHAMPS, C. e MORAES, A. Estrutura da pastagem, fotossíntese e produtividade de gramíneas forrageiras. PUBVET, Londrina, V. 6, N. 21, Ed. 208, Art. 1387, 2012.

vertical entre as folhas vai sendo reduzida, a distribuição da luz no dossel torna-se progressivamente mais irregular reduzindo, assim, a fotossíntese e, conseqüentemente a produção de forragem (LUDLOW et al.,1982). Quando as folhas distribuem-se de forma regular são capazes de interceptar mais luz que quando agrupadas, pois o auto-sombreamento reduz a interceptação luminosa (LANTINGA et al. 1999; COSTA et al., 2011). Quanto mais uniforme e regular a distribuição da área foliar ao longo do perfil vertical do dossel forrageiro, melhor a taxa de crescimento da cultura, como conseqüência do menor $\mathrm{K}$. Em pastagens de Lolium perenne (L.) que apresentavam dois tipos de arquitetura de plantas (prostradas e eretas), Pearson \& Ison (1987) constataram menor valor de $\mathrm{K}$ para as plantas eretas, o qual foi correlacionado com maior altura e maior rendimento de MS (Figura 6). No entanto, o uso de cultivares com uma arquitetura foliar mais eficiente na captação de luz as torna mais eficazes fotossinteticamente e, consequentemente, são mais exigentes em água e nutrientes, pois quanto maior a interceptação solar pelas folhas, maior será a fotossíntese e a transpiração, condições metabólicas que demandam mais energia pela planta.
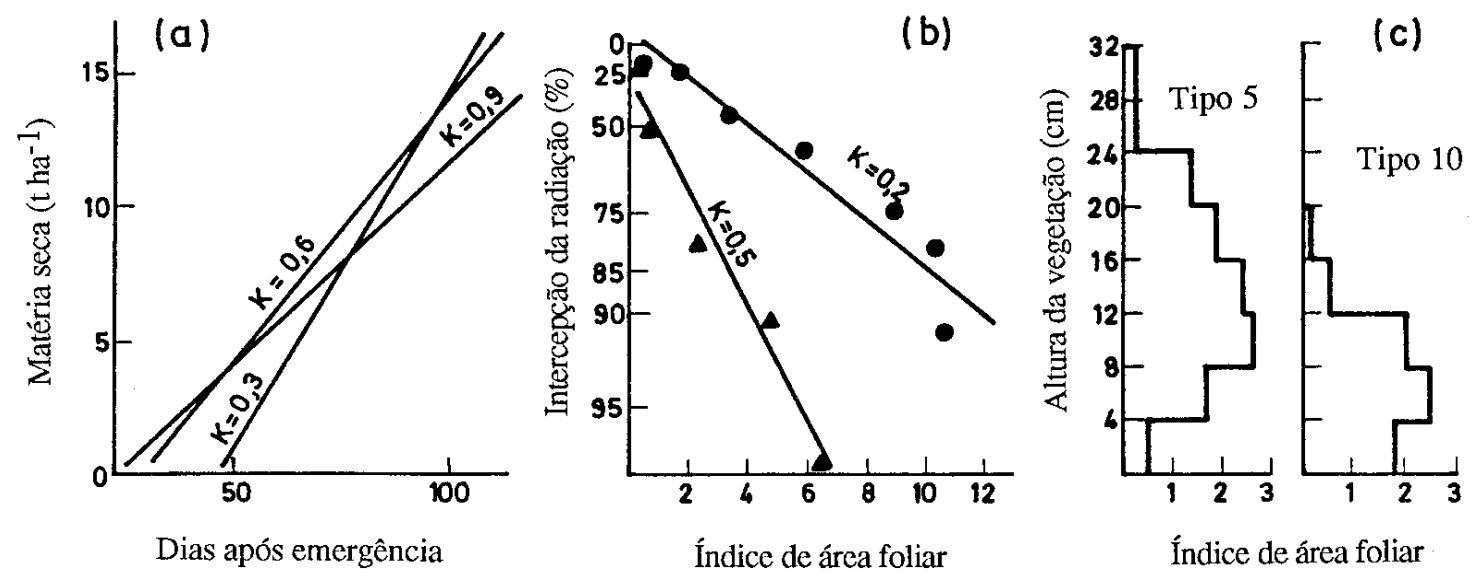

Figura 6. Crescimento e arquitetura da vegetação. (a) Efeito do coeficiente de extinção (K) no crescimento inicial e ritmo de crescimento da cultura. (b) Efeito conjugado do IAF e do $\mathrm{K}$ na intercepção da radiação pela cultura. (c) Diferença na estrutura da pastagem de Lolium perenne (L.) "tipo 5", com caules eretos e folhas longas, e "tipo 10" com caules prostrados e folhas curtas e menos rígidas (PEARSON; ISON, 1987) 
COSTA, N.L., DESCHAMPS, C. e MORAES, A. Estrutura da pastagem, fotossíntese e produtividade de gramíneas forrageiras. PUBVET, Londrina, V. 6, N. 21, Ed. 208, Art. 1387, 2012.

As diferenças de interceptação de luz e na taxa de fotossíntese do dossel estão relacionadas com o ângulo foliar e ocorrem principalmente para a luz direta e são dependentes da elevação solar (BERNARDES, 1987). O ângulo de inserção foliar é importante, pois afeta a extensão da penetração da radiação solar no dossel. Monsi \& Saeki (1953) descreveram a relação entre a eficiência de absorção diária de luz e o IAF do dossel como sendo: $\mathrm{Ea}=\mathrm{K}_{1}\left(1-\mathrm{e}^{\mathrm{K} 2} \mathrm{IAF}\right)$, onde o coeficiente $K_{1}$ é determinado pelas propriedade óticas das folhas, sendo que o valor 0,95 pode ser usado para a maioria das espécies (LACA; LEMAIRE, 2000); o coeficiente $K_{2}$ é o coeficiente de extinção luminosa, dependente da estrutura geométrica do dossel forrageiro, podendo ser calculado pela equação de Beer-Lambert $\left(\mathrm{K}_{2}=-\left[\log _{\mathrm{e}}\left(\mathrm{PAR}_{\mathrm{i}} / \mathrm{PAR}_{0}\right)\right] / \mathrm{IAF}\right)$, assumindo que ao longo de um dossel homogêneo as folhas são distribuídas ao acaso (SHEEHY; COOPER, 1973). A disposição das folhas é afetada por diversos fatores como: 1) hábito de crescimento das plantas (capacidade de ocupação horizontal), 2) filotaxia (inserção das folhas sobre as hastes), 3) tamanho, forma e curvatura das folhas e 4) respostas plásticas às variações em intensidade luminosa, que promovem uma dispersão regulada a partir do perfilhamento, formação das folhas e alongamento de hastes e pecíolos (WARREN-WILSON, 1961). Fagundes (1999) avaliou o efeito de intensidades de pastejo (5, 10, 15 e 20 $\mathrm{cm}$ de altura do pasto) sobre o IAF e a interceptação luminosa (IL) em três cultivares de Cynodon spp. (Coastcross, Florakirk e Tifton 85). As pastagens mantidas mais altas apresentaram maiores valores de IAF, IL e $K$, o que foi correlacionado, provavelmente, a folhas maiores e mais horizontais, diminuindo a quantidade de luz propagada ao longo do perfil do dossel, em função da grande variação em forma, tamanho, espessura e ângulos foliares. Os maiores valores de IAF para a cultivar Tifton 85 não foram associados com maiores valores de $\mathrm{K}$, indicando uma variação em arquitetura e arranjo das folhas entre as cultivares estudadas. 
COSTA, N.L., DESCHAMPS, C. e MORAES, A. Estrutura da pastagem, fotossíntese e produtividade de gramíneas forrageiras. PUBVET, Londrina, V. 6, N. 21, Ed. 208, Art. 1387, 2012.

As folhas têm absorção mais alta quando sua lâmina dispõe-se perpendicularmente à luz incidente. Algumas plantas controlam a absorção de luz pelo acompanhamento do sol, ou seja, suas folhas ajustam continuamente a orientação de suas lâminas, de modo que elas permaneçam perpendiculares. As folhas assumem uma posição vertical ao nascer do sol, com uma acurácia de $\pm 15^{\circ}$, durante o transcorrer do dia até o pôr-do-sol, quando as lâminas retomam uma posição quase vertical, neste caso, voltadas para o oeste. Com este mecanismo a plantas evita sua exposição total à luz solar, minimizando o aquecimento e a perda de água, sendo denominada dia-heliotrópica (TAIZ; ZEIGER, 2004). Para um ângulo foliar de $0^{\circ}$ (folhas planófilas), as variações na produção de MS, em função do IAF ou da hora do dia são pequenas. Para um ângulo foliar de $80^{\circ}$ a produtividade de biomassa foi diretamente proporcional ao IAF, ocorrendo diferenças nos rendimentos de MS nas horas de maior disponibilidade de radiação direta, em relação às horas em que predomina a radiação difusa (Figura 7 ). As plantas com maior ângulo de inserção das folhas podem apresentar, como um todo, maior absorção de luz, além de proporcionarem maior nível de transmissão da luz ao longo de seu perfil (Figura 8). Folhas horizontais proporcionam a habilidade de interceptar mais luz com um IAF menor, o que não deve ser visto como uma vantagem em termos produtivos. Comprovando a teoria de que folhas eretas favorecem a distribuição de luz no perfil do dossel, Warren-Wilson (1961) simulou uma situação hipotética e demonstrou que com uma inclinação de $81^{0}$ a folha aumentou sua superfície iluminada em aproximadamente seis vezes, além de sua assimilação líquida total ser duas vezes maior que quando disposta horizontalmente, demonstrando que folhas mais eretas utilizam a luz mais eficientemente e que, para uma mesma área de projeção vertical, apresentam maior assimilação líquida que as horizontais. Mello \& Pedreira (2004) observaram aumentos do IAF de P. maximum CV. Tanzânia-1, sob lotação rotacionada, os quais foram correlacionados com o aumento de interceptação luminosa. A maior intensidade de pastejo (menor resíduo pós-pastejo) alterou a estrutura da pastagem, com relação à arquitetura do dossel, evidenciada pela redução nos ângulos foliares médios (folhas mais planas) ao longo das 
COSTA, N.L., DESCHAMPS, C. e MORAES, A. Estrutura da pastagem, fotossíntese e produtividade de gramíneas forrageiras. PUBVET, Londrina, V. 6, N. 21, Ed. 208, Art. 1387, 2012.

estações do ano, resultando em maior interceptação luminosa por unidade de área foliar.
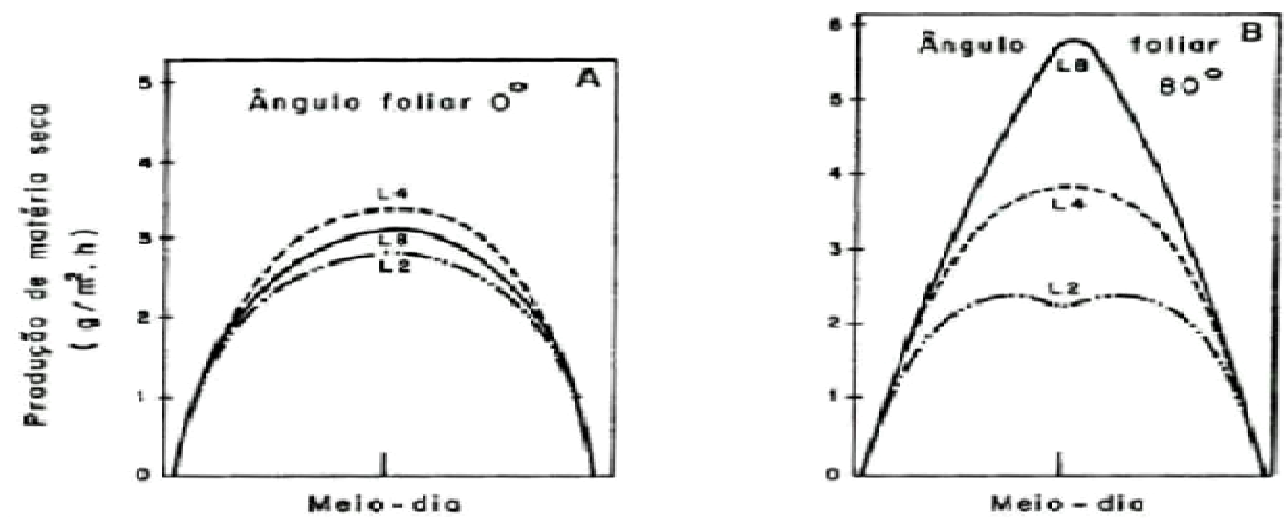

Figura 7. Valores teóricos de produção de matéria seca para milho em dois ângulos foliares $\left(A=0^{\circ}, B=80^{\circ}\right)$, em função do IAF (2, 4 e 8)(GARDNER et al., 1985)
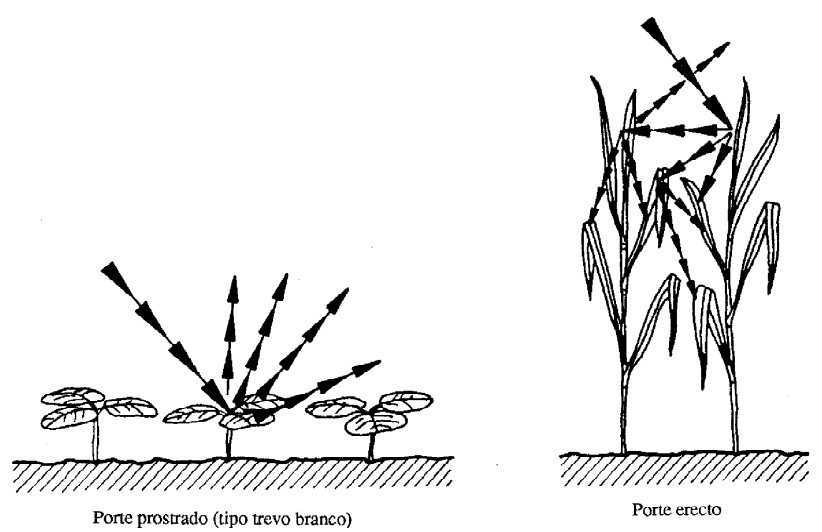

Figura 8. Ação da arquitetura da vegetação sobre a reflexão da luz; perda ou distribuição pelas folhas no interior do dossel (GILLET, 1980).

\subsection{Práticas de manejo, fotossíntese e produtividade de forragem}

As plantas forrageiras, ao longo de sua evolução, desenvolveram mecanismos de resistência e adaptação ao pastejo como forma de assegurar sua sobrevivência e persistência nas áreas de pastagem. A desfolhação representa um distúrbio ao crescimento da planta, afetando sua habilidade competitiva dentro da comunidade. As respostas à desfolhação podem ser vistas como estratégias de recuperação e manutenção do equilíbrio dinâmico do processo de acúmulo de forragem, situação em que todos os recursos 
COSTA, N.L., DESCHAMPS, C. e MORAES, A. Estrutura da pastagem, fotossíntese e produtividade de gramíneas forrageiras. PUBVET, Londrina, V. 6, N. 21, Ed. 208, Art. 1387, 2012.

devem ser utilizados de modo a maximizar o crescimento após a desfolhação. A desfolhação não afeta somente uma única planta, mas também as plantas vizinhas, modificando o ambiente luminoso e alterando a competição por luz (LEMAIRE, 2001). A principal adaptação fisiológica das plantas após a desfolhação é a alocação preferencial de carbono para os meristemas apicais de perfilhos e zonas de expansão foliar com o objetivo de maximizar o aparecimento e alongamento de novas folhas. Adaptações morfológicas como aumento da área foliar especifica ( $\mathrm{cm}^{2}$ de folha/g de MS de lâmina foliar), permitem a formação de uma área foliar mais eficiente (CARVALHO, 2002). As folhas recém-expandidas e em expansão possuem maior eficiência fotossintética que as maduras ou em senescência, sendo responsáveis por aproximadamente $75 \%$ da fotossíntese da planta (PARSONS et al., 1988; BRAGA, 2004). A baixa a luminosidade e alto nível de nutrientes no solo favoreceram a produção de folhas, enquanto que, alta luminosidade e baixo nível de nutrientes favoreceram a produção de raízes (OLFF, 1992). Em pastagens de $B$. brizantha cv. Xaraés, Pedreira \& Pedreira (2007) constataram que a taxa fotossintética das folhas individuais foram reduzidas com a menor freqüência de pastejo, comprometendo o potencial fotossintético do dossel e gerando atraso na rebrota da gramínea. O manejo adequado das plantas forrageiras deve priorizar o uso da luz pelo dossel, resultando em maior taxa fotossintética. A menor freqüência de desfolhação gera competição por luz e reduz a fotossíntese foliar e do dossel. Neste contexto, o manejo adequado da gramínea consiste em intervalos de pastejo menores que 28 dias, a fim de possibilitar maiores valores de fotossíntese de dossel ao longo do ciclo de rebrota.

A reconstituição da área foliar demanda energia e esqueleto carbônico. Após uma desfolhação severa, o balanço de carbono torna-se temporariamente negativo não suprindo a demanda para manutenção e crescimento da planta forrageira. Nos primeiros dias de rebrota ocorre acentuada queda no nível de reservas orgânicas, utilizadas para a respiração e restituição da área foliar, seguida de recuperação ao nível anterior à desfolha. O rendimento de MS 
COSTA, N.L., DESCHAMPS, C. e MORAES, A. Estrutura da pastagem, fotossíntese e produtividade de gramíneas forrageiras. PUBVET, Londrina, V. 6, N. 21, Ed. 208, Art. 1387, 2012.

durante a rebrota é proporcional à área foliar e à percentagem de meristemas apicais remanescentes após a desfolha (GOMIDE; ZAGO, 1980; BOTREL; GOMIDE, 1981), intensifica-se com o aumento no IAF e, com ele, a interceptação da radiação luminosa. Após a saída dos animais, a pastagem apresenta baixo IAF e predominância de folhas inferiores, mais velhas $\left(L_{3}\right)$; após os primeiros dias de descanso, observa-se predominância de folhas emergentes $\left(L_{1}\right)$ e subsequentemente, de folhas recém-expandidas $\left(L_{2}\right)$. A proporção de folhas emergentes e recém-expandidas aumenta consideravelmente com o decorrer do período de descanso (Figura 9), concomitantemente com a taxa de fotossíntese bruta do dossel ( $\mathrm{g}$ de $\mathrm{CO}_{2} / \mathrm{m}^{2} /$ hora) cresce assintoticamente com o período de rebrota, refletindo em maior IAF (KING et al., 1984; PARSONS et al., 1988) e o avanço da idade média da área foliar. Nos primeiros dias, a fotossíntese bruta do dossel foi inferior àquela observada sob pastejo contínuo intenso ( $\mathrm{IAF}=1,0$ ), porém igualou-a rapidamente, excedendo-a após 15 dias, quando predominavam as folhas recém-expandidas (Figura 10).

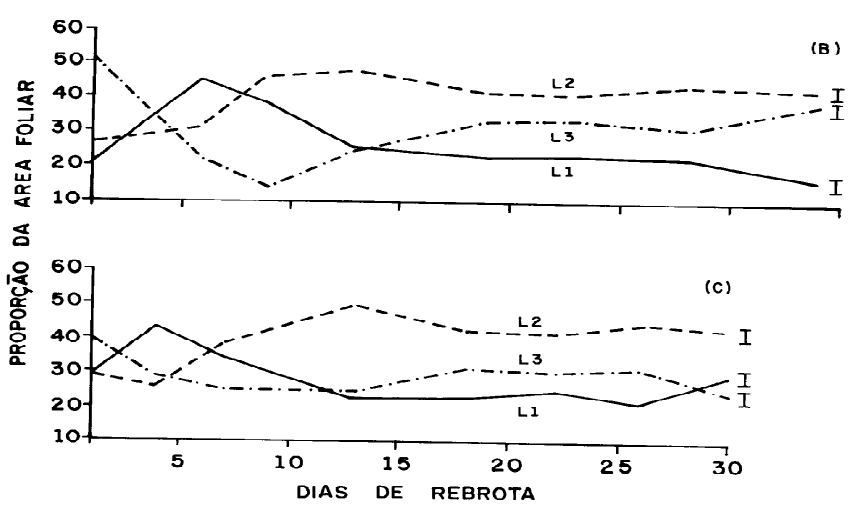

Figura 9. Evolução da proporção de folhas de diferentes idades de Lolium perenne (L.) durante 0 período de rebrota. b) Maior IAF $\mathrm{F}_{\text {remanescente; }}$ C) Menor $I A F_{\text {remanescente }}$ (PARSONS et al, 1988). 
COSTA, N.L., DESCHAMPS, C. e MORAES, A. Estrutura da pastagem, fotossíntese e produtividade de gramíneas forrageiras. PUBVET, Londrina, V. 6, N. 21, Ed. 208, Art. 1387, 2012.

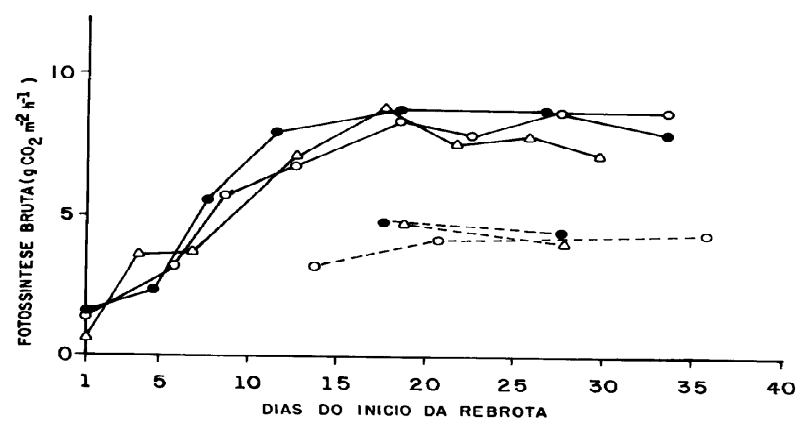

Figura 10. Evolução da fotossíntese bruta do dossel durante a rebrota de Lolium perenne (L.) sob pastejo rotacionado (-) e contínuo (---), mantendo o IAF = 1,0 (PARSONS et al, 1988).

A estabilização da fotossíntese bruta do dossel (Figura 11) é conseqüência de diversos fatores: reduzida eficiência fotossintética da área foliar decorrente de sua idade avançada, mútuo sombreamento das folhas (WOLEDJE; LEAFE, 1976) e plena interceptação da radiação luminosa (PARSONS et al., 1983). A produção bruta de forragem, isto é, fotossíntese líquida da pastagem azevém perene ( $L$. perenne L.), alcança valor máximo durante o período de descanso, quando $95 \%$ da radiação luminosa é interceptada. Neste momento, o relvado apresentaria também a máxima taxa de produção líquida de forragem e $I_{A} F_{\text {teto, }}$ visto que a partir de então, a proporção de folhas senescentes seria semelhante a de produção de novas folhas (PARSONS et al., 1983). Parsons et al. (1993), utilizando o modelo de fluxo de tecido em relvados de azevém perene sob lotação contínua, demonstraram o efeito da intensidade da desfolhação mantida em alto IAF, a formação de biomassa é próximo do máximo. Porém, para assegurar alto IAF é necessário que apenas uma pequena parte dos tecidos produzidos seja consumida, resultando em uma considerável proporção de folhas verdes remanescentes, contudo a alta taxa de fotossíntese contribui com grandes perdas de ganho/animal por área. Aumentando a intensidade de desfolhação, maior proporção de tecido foliar é removida, o que pode neutralizar, parcialmente, as perdas por senescência, pois há maior remoção de forragem pelos animais. Entretanto, se o consumo de biomassa aumenta, a grande remoção de tecidos fotossinteticamente ativos reduzem consideravelmente o IAF (Figura 12). Estas considerações implicam 
COSTA, N.L., DESCHAMPS, C. e MORAES, A. Estrutura da pastagem, fotossíntese e produtividade de gramíneas forrageiras. PUBVET, Londrina, V. 6, N. 21, Ed. 208, Art. 1387, 2012.

que, numa situação de lotação contínua, a manutenção do IAF próximo daquele da máxima interceptação da radiação, não coincide com a máxima produção colhível pelo animal (NABINGER, 1997), a qual é obtida num IAF abaixo do ótimo para produção de biomassa, mas que permite a melhor oportunidade de colheita do material vivo (PARSONS, 1988). Algumas gramíneas utilizam a estratégia de aumentar a duração de vida das folhas, como forma de manter níveis satisfatórios de fotossíntese e reduzir os efeitos negativos da desfolhação (DOBARRO et al., 2012). Em pastagens de $P$. maximum cv. Tanzânia, Cândido et al. (2005) verificaram que longos períodos de descanso propiciaram incrementos de IAF e biomassa com grande acúmulo de colmos no dossel, comprometendo a relação folha/colmo e reduzindo os índices de crescimento do dossel (taxa de assimilação líquida, taxa de crescimento relativo e PAR). A interceptação da PAR, após incrementos nas primeiras semanas, estabilizou-se em torno de 95-98\%, ao final do período de descanso. O acúmulo de colmos, na faixa de estabilidade da interceptação da PAR, foi o principal fator determinante do incremento de MS (Figura 13).

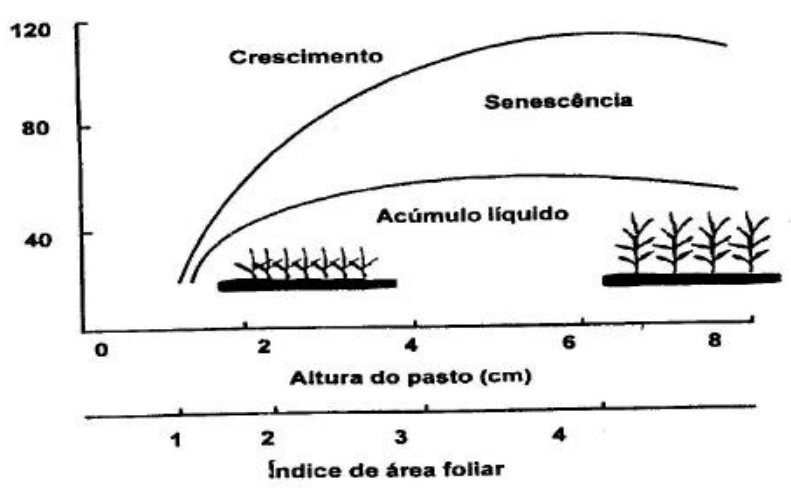

Figura 11. Variações nas taxas de fotossíntese bruta, perdas respiratórias, senescência, morte de tecidos e acúmulo de forragem durante a restauração do IAF de Lolium perenne (L.)(PARSONS et al, 1983). 
COSTA, N.L., DESCHAMPS, C. e MORAES, A. Estrutura da pastagem, fotossíntese e produtividade de gramíneas forrageiras. PUBVET, Londrina, V. 6, N. 21, Ed. 208, Art. 1387, 2012.
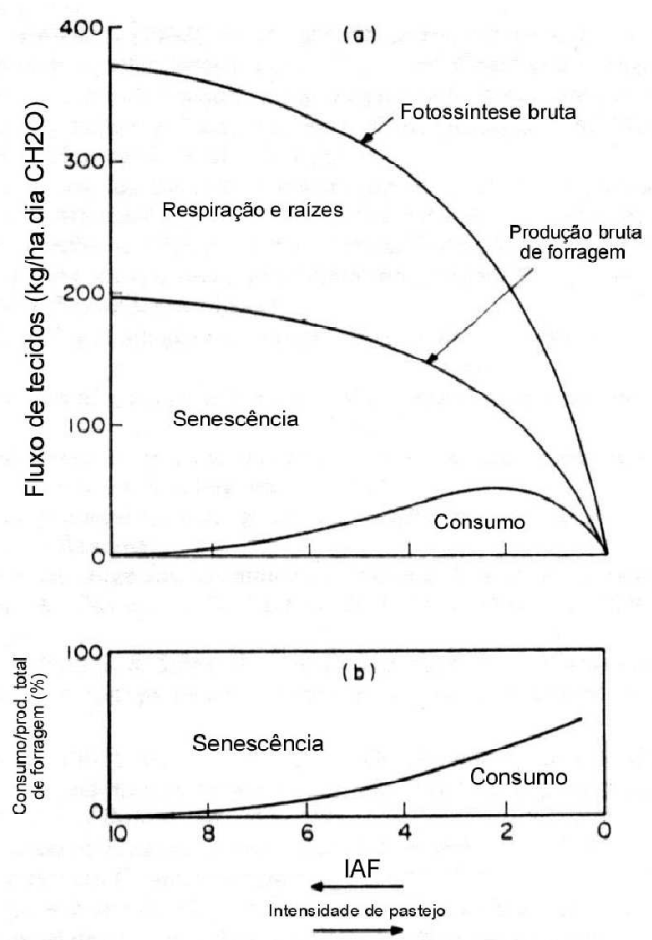

Figura 12. Efeito da intensidade do pastejo, sob lotação contínua, sobre os componentes da produção e o consumo de uma pastagem mantida a diferentes níveis de IAF (PARSONS et al., 1983).

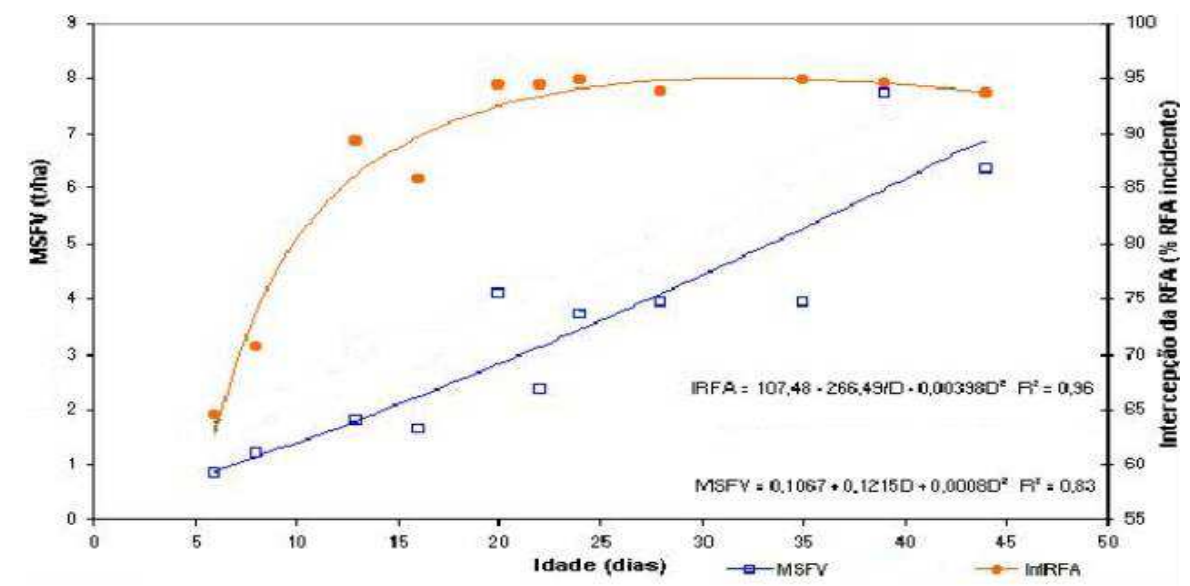

Figura 13. Intercepção de radiação fotossinteticamente ativa (IRFA) e matéria seca de forragem verde (MSFV), em dossel de Panicum maximum cv. Mombaça, após roçagem da pastagem (CÂNDIDO et al., 2005). 
COSTA, N.L., DESCHAMPS, C. e MORAES, A. Estrutura da pastagem, fotossíntese e produtividade de gramíneas forrageiras. PUBVET, Londrina, V. 6, N. 21, Ed. 208, Art. 1387, 2012.

\section{Considerações Finais}

O manejo eficiente e sustentável das pastagens pode ser caracterizado como o controle das relações do sistema pastoril, visando sua maior produção, melhor utilização e persistência, com reflexos positivos no desempenho zootécnico dos animais. A produção de forragem decorre da transformação de energia solar em compostos orgânicos através da fotossíntese, onde o carbono do dióxido de carbono $\left(\mathrm{CO}_{2}\right)$ da atmosfera é combinado com a água e convertido em carboidratos com a utilização da energia solar, processo responsável por mais de $90 \%$ do acúmulo de biomassa nas plantas. Fatores como temperatura, luz, água e nutrientes influenciam o potencial fotossintético da planta forrageira, como decorrência de modificações no seu índice de área foliar e na sua capacidade fotossintética do dossel.

A radiação luminosa, considerando-se sua ilimitada disponibilidade, é um dos fatores determinantes ao crescimento das plantas, através dos seus efeitos sobre a fotossíntese e outros processos fisiológicos, como a transpiração e a absorção de água e nutrientes. A seleção de germoplasma forrageiro, com arquitetura de plantas e estrutura de dossel, que maximizem a interceptação e utilização da luz é uma vantagem competitiva, proporcionando maior eficiência na transformação de energia luminosa em química. Neste contexto, práticas de manejo adequadas são essenciais para otimizar a geração e a dinâmica do fluxo de tecidos no ecossistema de pastagem, de modo a equilibrar a conflitante demanda das plantas por área foliar e a sua constante remoção através do consumo animal.

\section{Referências Bibliográficas}

AGATA, W.; KAWAMITSU, Y.; HAKOIAMA, S. Characteristics of photosynthesis, transpiration and water use efficiency of $\mathrm{C}_{3}$ e $\mathrm{C}_{4}$ grasses leaves. In: INTERNATIONAL GRASSLAND CONGRESS, 15., 1995, Kioto. Proceedings... Kioto: Kyushu University, 1985. p.347-349.

ACOCK, B.; CHARLES-EDWADS, D.A.; FITTER, D.J. et al. The contribution of leaves from different levels within a tomato crop to canopy net photosynthesis: an experimental examination of two canopies models. Journal of Experimental Botany, v.29, p.815-827, 1978. 
BISCOE, P.V.; SCOTT, R.K.; MONTEIH, J.L. Barley and its environment. III. Carbon budget of the stand. Journal of Applied Ecology, v.12, p.269-293, 1975.

BONHOMME, R. Beware of comparing RUE values calculated from PAR vs. solar radiation or absorbed vs. intercepted radiation. Field Crops Research, v.68, p.247-252, 2000.

BOTREL, M.A., GOMIDE, J.A. A importância dos carboidratos de reserva e da sobrevivência dos meristemas apicais para a rebrota do capim-jaragúa. Revista da Sociedade Brasileira de Zootecnia, v.10, n.3, p.411-426, 1981.

BRAGA, G.J. Assimilação de carbono, acúmulo de forragem e eficiência de pastejo em pastagens de capim-marandu [Brachiaria brizantha (Hochst ex A. Rich) Stapf.] em resposta à oferta de forragem. 2004. Tese (Doutorado em Ciência Animal e Pastagens). Universidade de São Paulo: Piracicaba: ESALQ, 2004.

BRAGA, G.J.; PEDREIRA, C.G.S.; HERLING, V.R. et al. Atenuação da capacidade fotossintética do dossel de uma pastagem de Brachiaria brizantha cv. Marandu. In: REUNIÃO ANUAL DA SOCIEDADE BRASILEIRA DE ZOOTECNIA, 39., 2002, Recife. Anais... Recife: SBZ, 2002. 3p. (CD-ROM).

BRAGA, G.J.; PEDREIRA, C.G.S.; HERLING, V.R. et al. Sward structure and herbage yield of rotationally stocked pastures of 'Marandu' palisadegrass [Brachiaria brizantha (A.Rich.)Stapf] as affected by herbage allowance. Scientia Agricola, v.63, n.2, p.121-129, 2006.

BERNARDES, M.S. Fotossíntese no dossel de plantas cultivadas. In: CASTRO, P.R.C.; FERREIRA, S.O.; YAMADA, T. (Eds.). Ecofisiologia da produção agrícola. Piracicaba: Associação Brasileira de Potassa e de Fosfato, 1987. p.13-48.

BROUGHAM, R.L. Interception of light by the foliage of pure mixed stands of pasture plants. Australian Journal Agricultural Research, v. 9, p.39-52, 1957.

BROWN, R.H.; COOPER, R.B.; BLASER, R.E. Effects of leaf age on efficiency. Crop Science, v.6, n.2, p. 206-209, 1966.

CÂNDIDO, M.J.D.; ALEXANDRINO, E.; GOMIDE, J.A. Duração do período de descanso e crescimento do dossel de Panicum maximum cv. Mombaça sob lotação intermitente. Revista Brasileira de Zootecnia, v.34, n.2, p.398-405, 2005.

CARVALHO, D.D. Leaf morphogenesis and tillering behaviour in single plants and simulated swards of Guinea grass (Panicum maximum Jacq.) cultivars. Palmerston North: Massey University, 2002. Thesis (Ph.D in Plant Science).

CHAPMAN, D; LEMAIRE, G. Morphogenetic and structural determinants of plant regrowth after defoliation. In: INTERNATIONAL GRASSLAND CONGRESS, 17., Palmerston North, 1993. Proceedings... Palmerston North: New Zealand Grassland Association, 1993. p.95-104.

COSTA, L.C.; MORISON, J.I.L.; DENNET, M.D. Carbon balance of growing faba bean and its effect on crop growth: experimental and modeling approaches. Revista Brasileira de Agrometeorologia, v.4, p.11-17, 1996.

COSTA, N. de L. Formação, manejo e recuperação de pastagens em Rondônia. Porto Velho: Embrapa Rondônia, 2004, 217p.

COSTA, N de L.; MAGALHÃES, J.A.; PEREIRA, R.G.A. et al. Considerações sobre o manejo de pastagens na Amazônia Ocidental. Revista do Conselho Federal de Medicina Veterinária, Brasília, v.13, n.40, p.37-56, 2007.

COSTA, N. de L.; MORAES, A., GIANLUPPI, V. et al. Acúmulo de forragem e efciência de utilização da radiação em pastagens de Axonopus aureus, durante o período seco, nos cerrados de Roraima. Revista Agro@mbiente On-line, Boa Vista, v.5, n.2, p.143-147, 2011. 
DALE, J.E. Some effects of temperature an irradiance on growth of the first four leaves of wheat Triticum aestivum. Annals of Botany, v.50, p.851-858, 1982.

DAVIES, A. Leaf tissue remaining after cutting and regrowth in perennial ryegrass. Journal of Agriculture Science, v.82, p.165-172, 1974.

DEREGIBUS, V.A.; SANCHEZ, R.A.; CASAL, J.J. Effects of light quality on tiller production in Lolium spp. Plant Physiology, v.72, p.900-912, 1983.

DOBARRO, I.; GAZOL, E.; PECO, B. Relative contribution of delaying senescence to growth compensation after defoliation. Ecological Research, v.27, n.2, p.475-479, 2012.

DURAND, J.L.; VARLET-GRANCHER, C.; LEMAIRE, G. et al. Carbon partitioning in forage crops. Acta Biotheorica, v.39, p.213-224, 1991.

FAGUNDES, J.L. Efeito de intensidades de pastejo sobre o índice de área foliar, interceptação luminosa e acúmulo de forragem em pastagens de Cynodon spp. Piracicaba: ESALQ, 1999. Dissertação de Mestrado. 69p.

GALLAGHER, J.N.; BISCOE, P.V. Radiation absorption, growth and yield of cereals. Journal of Agricultural Science, v. 91, p.47-60, 1978.

GARDNeR, F.P.; PEARCE, R.B.; MITCHELL, R.L. Physiology of crop plants. Ames: Iowa State University, 1985. 327p.

GILLET M. Les graminées fourragères: description, fonctionnement, application à la culture de I'herbe. Paris: Bordas, 1980.306p.

GOMIDE, J.A. Morfogênese e análise de crescimento de gramíneas tropicais. In: SIMPÓSIO INTERNACIONAL SOBRE PRODUÇÃO ANIMAL EM PASTEJO, Viçosa, 1997. Anais... Viçosa: UFV, 1997. p.411-429.

GOMIDE, J.A., ZAGO, C.P. Crescimento e recuperação do capim-colonião após corte. Revista da Sociedade Brasileira de Zootecnia, v.9, n.2, p.293-305, 1980.

GOSSE, G.; VARLET-GRANCHER, C.; BONHOMME, R. et al. Production maximile de matiere seche et rayonnement solaire intercepté par un couvert vegetal. Agronomic, v.6, p.47-56, 1986.

GRANT, S.A.; BERTHARM, G.T.; TORVELL, L. et al. Comparison of herbage production under continuous stocking and intermittent grazing. Grass and Forage Science, v.43, n.1, p.29-39, 1988.

HAY, R.K.M.; WALKER, A.J. An introduction to the physiology of crop yield. Essex: Longman Scientific and Technical, 1989, 292 p.

HODGSON, J. Grazing management: science into practice. New York: Longman Scientific \& Technical, 1990. 203p.

HOFSTRA, J.J.; STIENSTRA, A.W. Growth and photosynthesis of closely related $\mathrm{C}_{3}$ and $\mathrm{C}_{4}$ grasses, as influenced by light intensity and water supply. Acta Botanica Neerlondica, v.26, p.63-72, 1977.

LACA, E. A.; LEMAIRE, G. Measuring sward structure. In: t'MANNETJE, L.; JONES, R. M. (Eds.) Field and laboratory methods for grassland and animal production research. New York: CABI, 2000, p.103-122.

KING, J., SHIN, E.M., GRANT, S.A. Photoshynthetic rate and carbon balance of grazed ryegrass pastures. Grass and Forage Science, v.39, n1, p.81-92, 1984. 
LEMAIRE, G. The physiology of grass growth under grazing: tissue turnover. In: SIMPÓSIO INTERNACIONAL SOBRE PRODUÇÃ̃O ANIMAL EM PASTEJO, Viçosa, 1997. Anais... Viçosa: UFV, p.115-144, 1997.

LEMAIRE, G.; AGNUSDEI, M. Leaf tissue tunover and efficiency of herbage utilization. In: MORAES, A. (Ed.). INTERNATIONAL SYMPOSIUM ON GRASSLAND ECOPHYSIOLOGY AND GRAZING ECOLOGY, 1., 1999, Curitiba. Anais... Curitiba: UFPR, 1999. p.165-186 .

LEMAIRE, G.; CHAPMAN, D. Tissue flows in grazing plant communities. In: HODGSON, J.; ILLIUS, A.W. (Eds.). The ecology and management of grazing systems. Wallingford: CAB International, 1996. p.3-36.

LANTINGA, E.A.; NASSIRI, M.; KROPFF, M.J. Modeling and measuring vertical absorption within grass-clover mixture. Agricultural and Forest Meteorology, v.96, p.71-93, 1999.

LAWLOR, D.W. Photosynthesis, productivity and environment. Journal of Experimental Botany, v.46, p.1449-1461, 1995.

LEMAIRE, G. Ecophysiology of grasslands: dynamics aspects of forage plant populations in grazed swards. INTERNATIONAL GRASSLAND CONGRESS, 19., São Pedro, 2001. Proceedings... São Paulo: ESALQ, 2001, p.29-37.

LOOMIS, R.S.; GERAKIS, P.A. Productivity of agricultural systems. In: COOPER, J.P. (Ed.) Photosynthesis and productivity in different environments. Cambridge: Cambridge University Press, p.145-172, 1975.

LOOMIS, R.S.; WILLIAMS, W.A. Productivity and the morphology of crop stands: patterns with leaves. In: EASTIN, J.D.; HASKINS, F.A.; SULLIVAN, C.Y. et al. (Eds.). Physiological aspects of crop yield. Madison: ASA/CSSA/SSA, 1969. p.27-47.

LUDLOW, M.M. Photosyntesis and dry matter production in $C_{3}$ and $C_{4}$ pasture plants with special emphasis on tropical $\mathrm{C}_{3}$ legumes and $\mathrm{C}_{4}$ grasses. Australian Journal of Plant Physiology, v.12, n.6, p.557-572, 1985.

LUDLOW, M.M.; STOBB, T.H.; DAVIS, R. CHARLES-EDWARDS, D.A. Effect of sward structure of two tropical grasses with contrasting canopies on light distribution, net photosynthesis and size of bite harvested by grazing cattle. Australian Journal of Agricultural Research, v.33, p.187-201, 1982.

MATHEW, C; ASSUERO, S.G.; BLACK, C.K. et al. Tiller dynamics of grazed swards. In: LEMAIRE et al. (Eds.) Grassland ecophysiology and grazing ecology. Wallingford: CABI International, 2000, p.127-150.

MELLO, A.C.L.; PEDREIRA, C.G.S. Respostas morfológicas do capim-Tanzânia (Panicum maximum Jacq. cv. Tanzânia-1) irrigado à intensidade de desfolha sob lotação rotacionada.

Revista Brasileira de Zootecnia, v.33, n.2, p.282-289, 2004.

MELLO, A.C.L.; SANTOS, P.M.; PEDREIRA, C.G.S. et al. Phothosynthetic light response of Tanzania grass under four levels of leaf temperature. In: INTERNATIONAL GRASSLAND CONGRESS, 19., 2001, São Pedro. Proceedings... Piracicaba: FEALQ, 2001. p. 73-74.

MILTHORPE, F.L.; DAVIDSON, J.L. Physiological aspects of regrowth in grasses. In: MILTHORPE, F.L.; IVINS, J.D. (Eds). The growth of cereals and grasses. London: Butterworths, 1966, p.241-254.

MONTEITH, J.L. Climate and the efficiency of crop production in Britain. Philosophical Transactions of the Royal Society, London, v.281, p.227-294, 1977.

MONTEITH, J.L. Light distribution and photosynthesis in field crops. Annals of Botany, v.29, p.17-37, 1965. 
MONSI, M.; SAEXI, T. Über der lichtfaktor in den pflanzengesellschaften und seine Bedeutung fur die stoffproduktion. Japanese Journal of Botany, v.14, p.22-52, 1953.

NABINGER, C. Aspectos ecofisiológicos do manejo de pastagens e utilização de modelos como ferramenta de diagnóstico e indicação de necessidades de pesquisa. In: REUNIÃO DO GRUPO TÉCNICO REGIONAL DO CONE SUL (ZONA CAMPOS) EM MELHORAMENTOS E UTILIZAÇÃO DE RECURSOS FORRAGEIROS DAS ÁREAS TROPICAL E SUBTROPICAL, 1996., Porto Alegre. Anais... Porto Alegre: UFRGS, 1996. p.17-62.

NABINGER, C. Eficiência do uso de pastagens: disponibilidade e perdas de forragem. In: SIMPÓSIO SOBRE MANEJO DA PASTAGEM, 14., Piracicaba, 1997. Anais... Piracicaba: ESALQ, p.213-251, 1997.

NABINGER, C. Manejo da desfolha In: SIMPÓSIO SOBRE MANEJO DA PASTAGEM, 14., 2001, Piracicaba. Anais... Piracicaba: ESALQ, 2001. p.192-210.

OLFF, $\mathrm{H}$. Effects of light and nutrient a availability on dry matter and $\mathrm{N}$ allocation in six successional grassland species. Oecologia, v. 89, p.412-421, 1992.

PARSONS, A.J. Use of a model to optimize the interaction between frequency and severity of intermittent defoliation and to provide a fundamental comparison of the continuo and intermittent defoliation of grass. Grass and Forage Science, v.43, p.49-59, 1988.

PARSONS, A.J., JOHNSON, I.R., WILLIAM, J.H.H. Leaf age structure and canopy photosynthesis in rotationally and continuously grazed swards. Grass and Forage Science, v.43, n.1, p.1-4, 1988.

PARSONS, A.J.; PENNING, P.D. The effect of the duration of regrowth on photosynthesis, leaf death and the average rate of growth in a rotationally grazed sward. Grass and Forage Science, v.43, p.15-27, 1988.

PARSONS, A.J., LEAFE, E.L., COLLET, B. et al. The physiology of grass productions under grazing. 2. Photosynthesis, crop growth and animal intake of continuously grazed sward. Journal of Applied Ecology, v.20, n.1, p.127-139, 1983.

PARSONS, A.J.; LEAF, E.L.; COLLETT, B.; STILES, W. The physiology of grass production under grazing. 1. Characteristics of leaf and canopy photosynthesis of continuously grazed swards. Journal of Applied Ecology, v. 20, p. 117-126, 1993.

PEARSON, C.J.; ISON, R.L. Agronomy of grassland systems. Cambridge: Cambridge University Press, p.9-61, 1987.

PEDREIRA, C.G.S. Plant and animal responses on grazed pastures of "Florakirk" and "Tifton 85" Bermudagrass. Thesis of Doctor of Philosophy. University of Florida, Florida, 1995. 153p.

PEDREIRA, B.C.; PEDREIRA, C.G.S. Fotossíntese foliar do capim-xaraés [Brachiaria brizantha (A.Rich.) Stapf. cv. Xaraés] e modelagem da assimilação potencial de dosséis sob estratégias de pastejo rotativo. Revista Brasileira de Zootecnia, v.36, n.4, p.773-779, 2007.

ROBSON, M.M. A comparison of British and North American varieties of tall fescue. 1. Leaf growth during winter and the effect on it of temperature and daylenght. Journal of Applied Ecology, v.4, p.475-484, 1967.

ROBSON, M.J.; RYLE, G.J.A.; WOLEDGE, J. The grass plant: its form and function. In: JONES, M.B.; LAZENBY, A. (Eds.). The grass crop: the physiological basis of production. London: Chapman and Hall, p.25-83, 1988.

RUSSEL, G.; JARVIS, P.G.; MONTEITH, J.L. Absorption of radiation by canopies and stand growth. In: RUSSEL, G.; JARVIS, P.G.; MONTEITH, J.L. (Eds.) Plant canopies: their growth, 
form and function. Cambridge: Cambridge University, 1989. p.21-39. (Society for Experimental Biology Seminar Series, 31).

RYLE, G.J.A.; POWELL, C.E. Defoliation and regrowth in the graminaceous plant: the role of current assimilate. Annals of Botany, v.39, n.160, p.297-310, 1975.

SALOMÃO, K.; PEDREIRA, B.C.; LARA, M.A. et al. Fotossíntese foliar de capim Tobiatã depende da região da lâmina usada na medição. In: SIMPÓSIO INTERNACIONAL DE INICIAÇÃO CIENTÍFICA DA USP, 13., 2005, Piracicaba. Anais... Piracicaba: ESALQ, 2005. 1p. (CD-ROM).

SBRISSIA, A.F.; DA SILVA, S.C. O ecossistema de pastagens e a produção animal In: REUNIÃO ANUAL DA SOCIEDADE BRASILEIRA DE ZOOTECNIA, 38, Piracicaba, 2001. Anais... Piracicaba: SBZ, 2001, p.731-754.

SCHÖFFEL, E.R.; VOLPE, C.A. Eficiência de conversão da radiação fotossinteticamente ativa interceptada pela soja para produção de fitomassa. Revista Brasileira de Agrometeorologia, n.2, v.9, p.241-249, 2001

SHEEHY, J.E.; COOPER, J.P. Light interception, photosynthetic activity, and crop growth rate in canopies of six temperate forage grasses. Journal of Applied Ecology, v.10, p.239-250, 1973.

SHIBLES, R.M.; WEBER, C.R. Interception of solar radiation and dry matter production by various soybean planting patterns. Crop Science, v.6, p.55-59, 1966.

SHIBLES, R.M.; WEBER, C.R. Leaf area, solar radiation interception, and dry matter production by various soybean planting patterns. Crop Science, v.6, p.575-577, 1965.

SILVA JÚNIOR, L.C.; SILVA, W.J.; BISINOTTO, F.F. Efeito da radiação fotossinteticamente ativa no crescimento e desenvolvimento de gramíneas forrageiras. Belo Horizonte: EPAMIG, 2009, 4p.

SIVAKUMAR, M.V.K.; VIRMANI, S.M. Crop productivity in relation to interception of photosynthetically active radiation. Agricultural and Forest Meteorology, v.31, n.1, p.131$141,1984$.

SNAYDON, R.W. The productivity of $\mathrm{C}_{3}$ and $\mathrm{C}_{4}$ plants: a re-assessement. Functional Ecology, v.5, p.321-330, 1991.

TAIZ, L.; ZEIGER, E. Fisiologia Vegetal. Porto Alegre: Artmed, 3.ed., 2004. 719p.

TERASHIMA, I.; HIKOSAKA, K. Comparative ecophysiology of leaf and canopy photosynthesis. Plant, Cell and Environment, v.18, p.1111-1128, 1995.

TREHARNE, K.J., COOPER, J.P., TAYLOR, T.H. Growth response of orchardgrass (Dactylis glomerata L.) to different light and temperature environments; II. Leaf age and photosynthetic activity. Crop Science, v.8, n.4, p.441-445, 1968.

VOGELMANN, T.C.; BORNMAN, J.F.; YATES, D.J. Focusing of light by leaf epidermal cells. Physiology Plant, v.98, p.43-56, 1996.

WARREN-WILSON, J. Influence of spatial arrangement of foliage area on light interception and pasture growth. In: INTERNATIONAL GRASSLAND CONGRESS, 8., 1961, Berkshire. Proceedings... Berkshire: Alden Press, 1961. p.275-279.

WOLEDJE, J., LEAFE, E.L. Single leaf and canopy photosynthesis in a ryegrass sward. Annals of Botany, v.40, n68, p.773-783, 1976.

ZELITCH, I. The close relationship between net photosynthesis and crop yield. Bioscience, v.32, p.796-802, 1982. 